\title{
Ivana Sambolić Zaboravljeni memento mori iz Belca
}

\section{Ivana Sambolić Hrvatski restauratorski zavod Odjel za štafelajno slikarstvo isambolic@hrz.hr \\ Prethodno priopćenje / Preliminary communication \\ Primljen / Received: 2. 6. 2021}

UDK: 75.025.3/.4:[272-256(497.5 Belec)"17" DOI: https://doi.org/10.17018/portal.2021.7
SAŽETAK: U članku je predstavljen tijek događanja koja su imala posredni ili neposredni utjecaj na odabir ikonografije antependija s glavnog oltara crkve sv. Jurja u Belcu, koja je najznačajniji primjer srednjovjekovne ladanjske crkve u Hrvatskoj. Obostrano slikani antependij sv. Jurja, na čijoj je stražnjoj strani naslikan motiv memento mori, pronađen je 2016. godine u župnom dvoru, nakon čega su na njemu izvedeni cjeloviti konzervatorsko-restauratorski radovi. Cilj radova bio je omogućiti prezentaciju obiju strana antependija, zbog čega je posebno konstruiran okvir, $u$ čijoj se unutrašnjosti nalazi sistem s oprugama pomoću kojih je antependij napet. Osim navedenoga, članak donosi opis izvedenih radova i preispituje razloge za odabir ikonografskoga motiva memento mori sa stražnje strane antependija te na temelju rezultata istraživanja moguće uloge takvog prikaza tijekom vršenja liturgijskih obreda vezanih uz sahranu pokojnika, kao i drugih liturgijskih obreda vezanih uz pokojnike, a koji se nakon Drugog vatikanskog koncila u Župi Belec više nisu obavljali.

KLJUČNE RIJEČI: crkva sv. Jurja, Belec, obostrano slikani antependij, memento mori, rekvijem, „črna meša“, lubanja, Taborsko, Hrvatsko Zagorje
$\mathrm{N}$ a spomen imena mjesta Belec, prve će misli najčešće biti usmjerene na jednu od najljepših baroknih crkvi u Hrvatskoj, posvećenu sv. Mariji Snježnoj, no Župa Belec imala je do 1781. godine drugu crkvu kao župnu i drugog titulara - sv. Jurja, koji je mnogo stoljeća bio njezin zaštitnik. ${ }^{1}$ U stručnoj je literaturi ova crkva (sl. 1 i 2) često bila opisana riječima Gjure Szabe kao najzagonetnija crkvena građevina u cijelom Zagorju. ${ }^{2}$ Danas je crkva sv. Juraja jedina župna kapela, smještena je na blagom brežuljku te je oblikuju sljedeći glavni volumeni: poligonalno zaključeno svetište, šira i viša lađa te jednokatni toranj zvonik. Sa sjeverne je strane uz svetište prigrađena sakristija, a ulaz u kapelu je na zapadu, kroz toranj, dok se drugi ulaz nalazi na južnoj strani i nadsvođen je malim trijemom. U popisu župa iz 1334. godine ova se crkva spominje kao župna crkva (ecclesia sancti Georgi de Belch ${ }^{3}$ ) te slijedom navedenog crkveni povjesničar Vjekoslav Noršić zaključuje kako je belečka župa među najstarijima $u$ Zagorju. ${ }^{4} \mathrm{U}$ zapisima vizitacija nailazimo kod sv. Jurja navod „... sub Belecz“ , koji se tijekom mnogih godina zadržao kod opisa stanja na koje vizitator nailazi, jednako kao i u starim župnim zapisima, ${ }^{5}$ dajući do znanja kako su se naselja na području župe prostirala podno srednjovjekovne utvrde Belec, današnjeg Belecgrada, smještenog na južnim padinama Ivanščice. Najvažnija je djelatnost belečkog vlastelinstva krajem 15. stoljeća pa sve 


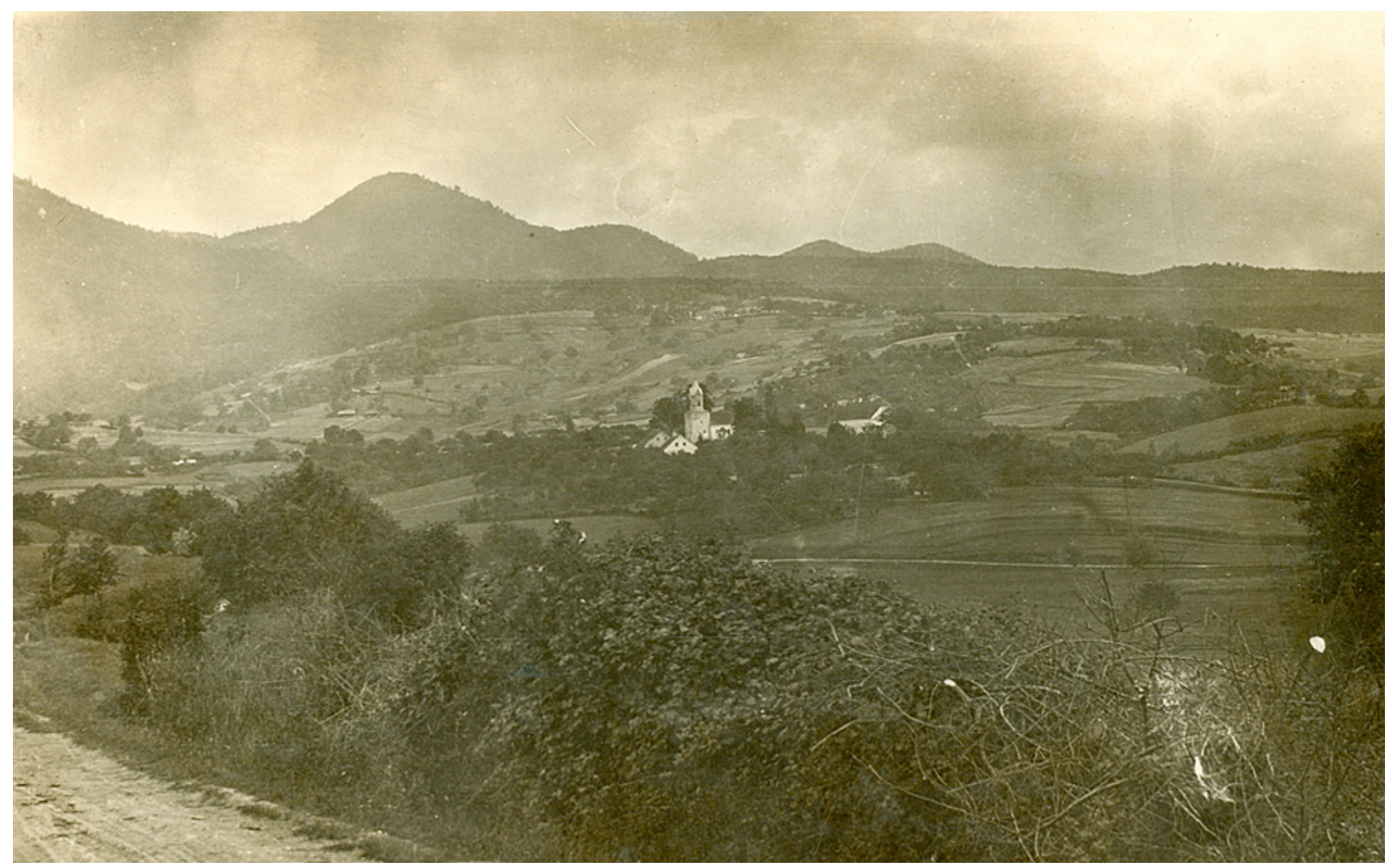

1. Belec, Crkva sv. Jurja u krajoliku, pogled prema sjeveru (MKM-FKB, snimka: Gj. Szabo, 1912., inv. br. 5330) Belec, Church of St George, view from the north (MKM-FKB, inv. no. 5330, Gj. Szabo, 1912)

do sredine 17. stoljeća bila vinogradarstvo. ${ }^{6}$ Podno utvrde Belec i pod zaštitom sv. Jurja, prema vizitaciji iz 1639. godine, nalazimo sljedeća sela koja pripadaju belečkoj župi: Gjuranczi, Zaùersie, Zelnicza, Zlatina, Hisanoùczy, Kordosseùczy, Petrusseùczy, Scherbinczy, Breziche, Repno, Klimen, Prepustoùczi i Batina. Ista naselja spominje i vizitacija iz 1677. godine, jedino nema naselja Korduševec, a umjesto Gjuranczi stoji Juranczy, dok selo Zlatina također s vremenom nestaje. Prvi opis crkve sv. Jurja u kanonskoj je vizitaciji iz 1639. godine, kada je crkva imala u zvoniku dva zvona, četiri oltara, novu propovjedaonicu i kor. Vizitator tada navodi loše stanje poda u kapeli u koju se sahranjuju lokalni plemenitaši koji nakon sahrane ne poravnavaju pod, a čak i napominje da bi im se moglo zabraniti sahranjivanje u crkvi zbog ovakvog nemara. ${ }^{7}$ Sa sjeverne strane bila je prigrađena kapela sv. Katarine i sakristija koja se spominje u vizitaciji iz 1729. godine. Oko crkve bilo je groblje ograđeno drvenom ogradom, unutar kojega se nalazila kapelica sv. Mihaela. Na ovo su se groblje pokapali svi župljani, osim onih iz Selnice, te djelomično iz Klimena i Prepuštovca, koji su se sahranjivali na groblju uz kapelu sv. Nikole. Kapela sv. Nikole spomenuta je i 1334. godine, a vizitacije kroz 17. stoljeće tek djelomično otkrivaju njezine karakteristike, navodeći sve veći broj oštećenja, sve dok nije stradala u potresu 13. listopada 1775 . godine tako da se u njoj više nije mogla odvijati služba te je s vremenom propala u tolikoj mjeri da se danas ni ne zna gdje se točno nalazila.
U tom je potresu i crkva sv. Jurja pretrpjela veliku štetu; stradale su tada kapela sv. Katarine i sakristija do te mjere da se više ni ne obnavljaju, već se gradi nova sakristija na sjevernoj strani, uz svetište. ${ }^{8}$ Kroz zapise iz vizitacija može se lako primijetiti kako je ova crkva sve više gubila na važnosti jer je u međuvremenu izgrađena crkva sv. Marije Snježne na mjestu zvanom Kostanjevec, udaljenom 1 km od crkve sv. Jurja. Sv. Marija Snježna, između 1739. i 1742. godine, raskošno je opremljena u baroknom stilu te se oko crkve formiralo naselje Belec, sve do Juranšćine. ${ }^{9}$ Sv. Juraj sve više pada u drugi plan, osobito kada je 1781. godine župnom crkvom proglašena crkva sv. Marije Snježne, a još više nakon potresa 1880 . godine, kada je crkva sv. Jurja dosta stradala.

Nešto prije vremena nastajanja Noršićevih bilješki o povijesti Župe Belec koje su korištene u ovom radu (1917. - 1925.), belečke crkve istražuje G. Szabo koji piše: „Među najzagonetnije crkvene građevine u cijelom Zagorja spada stara župna crkva u Belcu, koja danas služi kao kapela. “10 Ovaj zaključak zasigurno je najčešće citiran u stručnim radovima koji su se bavili crkvom sv. Jurja. Gjuri Szabi bila je zagonetka koji je dio crkve $u$ kojem razdoblju građen, s obzirom na velike razlike u pojedinim, kako sam kaže, građevnim dijelovima, te koja je bila prvotna funkcija tornja na kojem su vidljive stilske značajke romanike. Szabo pretpostavlja kako je najstariji dio crkve toranj/ zvonik, iz razdoblja romanike koji je nekad bio obrambeni toranj, tzv. Bergfried. ${ }^{11}$ Odgovor na pitanje koja je 
uloga ovog tornja i što se kroz povijest sve događalo na području belečke župe, svakako iziskuje daljnja istraživanja, pa tako i utvrde Belecgrad te okolnog područja, a neke odgovore pokušala su dati istraživanja i stručni radovi konzervatora i povjesničara umjetnosti koji su crkvu proučavali. U radu O građevinskim mjenama crkve sv. Jurja u Belcu - drugačije Drago Miletić njezinu izgradnju datira u razdoblje kraja 13. stoljeća i razmatra zaključke mnogih stručnjaka koji su se bavili crkvom sv. Jurja. ${ }^{12}$ Neke od njih pobija, kao npr. hipotezu Zdenka Baloga da je riječ o crkvi tipa Chorturm. ${ }^{13} \mathrm{U}$ navedenom radu Miletić iznosi teoriju da je toranj prvotno bio kosturnica ili karner belečkog veleposjednika na koji se kasnije nadovezuje lađa i svetište, a u prilog tomu ide i činjenica da je prilikom radova 1989. godine u podu svetišta uz sjeverni zid pronađen oštećeni kameni sarkofag iz razdoblja prije provale Tatara. Svoja zapažanja zaokružuje zaključkom kako na području kontinentalne Hrvatske nema drugih poznatih primjera karnera, pa se uz romaničko pročelje tornja zidano pravilnim klesancima i s jedinstvenim gotičkim svodom na kojemu je vidljivo obilje arhitektonske plastike s figuralnim, vegetabilnim i geometrijskim motivima, crkva sv. Jurja u Belcu svakako ubraja u najznačajnije primjere srednjovjekovne ladanjske župne crkve u Hrvatskoj. Gotovo svi istraživači crkve sv. Jurja navode je kao neizostavni primjer u razvoju umjetnosti srednjega vijeka, osobito na području kontinentalne Hrvatske. ${ }^{14}$ Kroz 20. stoljeće najčešće je korištena za služenje misa za pokojnike, i danas se u njoj povremeno služe mise, no najvažniji je događaj tradicionalna uskrsna procesija s Presvetim Oltarskim Sakramentom koja kreće od crkve sv. Jurja i završava u crkvi sv. Marije Snježne.

\section{Unutrašnjost crkve sv. Jurja}

Uz intrigantnu arhitekturu, vrlo su zanimljive i dinamične bile promjene u opremanju inventarom. Kako se mijenjao interijer, vrlo detaljno saznajemo iz Noršićevih bilješki:

„Pošto smo malo opširnije opisali samu crkvu, što ona radi svoje starine i punim pravom zaslužuje, vrijeme je da pogledamo i njezin unutarnji namještaj od vremena kako nam ju opisuju zapisnici kanoničkih vizitacija. Godine 1639. nalaze se u crkvi četiri oltara. Glavni u svetištu jest oltar sv. Jurja, zaštitnika župe. U ladji do svetišta, na strani evangjelja bio je oltar: Čudotvorne Krvi Isusove. Ovome oltaru nasuprot, na strani poslanice bio je oltar Majke Božje na nebo uzete. Četvrti oltar nalazio se u kapeli, na sjevernoj strani ladje i bio je posvećen sv. Katarini. Godine 1677. nema više u ladji oltara Krvi Isusove, već je na njegovom mjestu novi oltar Marije Magdalene. Isti oltari postoje u crkvi i g. 1708. Već g. 1729. nalazimo u crkvi drugi raspored oltara. Glavni sv. Jurja sa kipom svetca. $\mathrm{Na}$ strani evangjelja stoji priprosti oltar Majke Božje lauretanske sa slikom a suprot njemu, mjesto prijašnjeg oltara sv. Marije Magdalene, stoji oltar sv. Katarine, vrlo neugledan.

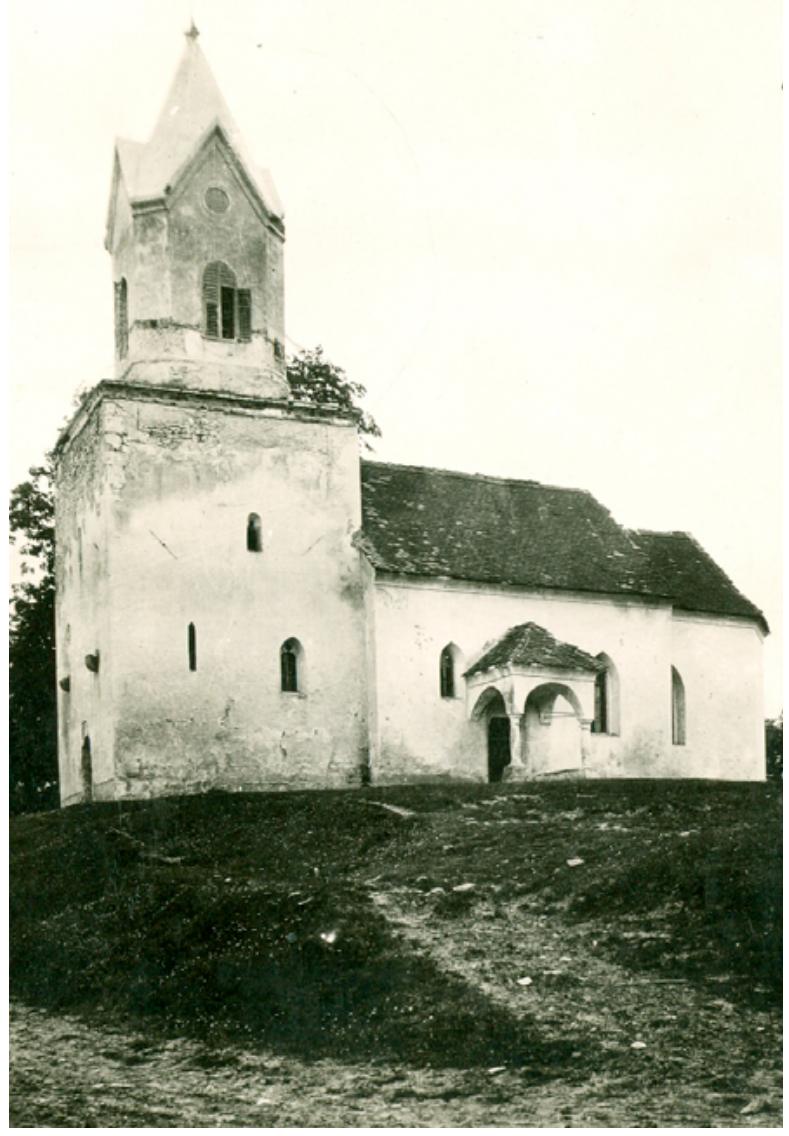

2. Crkva sv. Jurja, pogled s južne strane (MKM-FKB, snimka: Gj. Szabo, 1912., inv. br. 5333)

Church of St George, view from the south (MKM-FKB, inv. no. 5333, Gj. Szabo, 1912)

Kasniji zapisi vizita od g. 1732. - 1771. ne navode, ni ne opisuju oltara. Zapisnik od g. 1778. spominje tri posvećena oltara i neposvećeni sv. Križa bez sv. moći. Kad je porušena kapela sv. Katarine, nestalo je i istoimenoga oltara te su danas u crkvi tri oltara, od kojih je najvredniji glavni oltar sv. Jurja izradjen oko polovine 17. vijeka u stilu renaisanse. Ostala dva u ladji do svetišta Bl. Dj. Marije i sv. Križa bez svake su umjetničke vrijednosti. Crkva je imala već g. 1639. drveni kor i propovjedaonicu. Kor postoji još danas dok je propovjedaonica radi trošnosti u polovini 18. stoljeća odstranjena pak već g. 1758 . nalazimo mjesto nje novu nabavljenu troškom od 120 for. Ista je također bila od drva. Stajala je na strani evangjela u ladji na stupu. Na samoj propovjedaonici bila su četiri evangjelista a na njezinu krovu angjeo s trubljom i tri angjela /: genia:/. Ove propovjedaonice danas više nema u crkvi.“15 Tekst dalje navodi kako se u zapisnicima ne spominje da crkva ima vrjednijih misnih odijela ili drugih spomena vrijednih stvari, kako se do 1677 . godine nigdje ne spominje ni ikakav crkveni posjed te kako joj je jedina imovina bila klijet blizu crkve. 


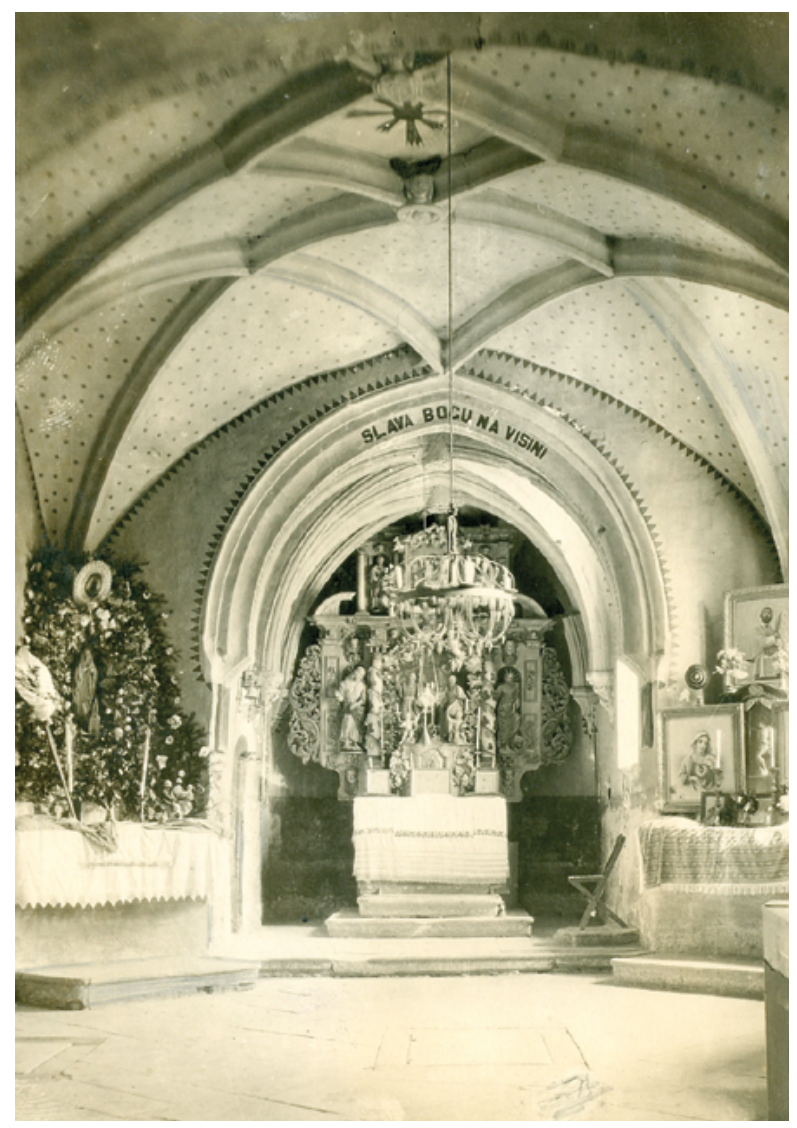

3. Crkva sv. Jurja, svetište s oltarom sv. Jurja iz 17. stoljeća i dva pokrajnja oltara (MKM-FKB, snimka: Gj. Szabo, 1912., inv. br. 5351)

Church of St George, sanctuary with the altar of St George $\left(17^{\text {th }}\right.$ century) and two side altars (MKM-FKB, inv. no. 5351, Gj. Szabo, 1912)

Svakako upada u oči kako ni Szabo ni Noršić ne navode u inventaru crkve antependij sv. Jurja, koji potječe s glavnog oltara, što je moguća posljedica opisivanja koje ne ide $u$ detalje, no moguće je i da $u$ tom razdoblju on nije bio postavljen na glavni oltar ili je možda bio prekriven. Najranije su fotografije kapele sv. Jurja iz 1912. godine, a riječ je o fotografijama koje je napravio Szabo prilikom popisivanja spomenika na području kotara Krapina i Zlatar (sl. 1, 2 i 3). Na fotografiji unutrašnjosti vidi se da je oltar bio postavljen na gotičku menzu u svetištu. U donjem dijelu retabla nalazi se tabernakul s anđelima lučonošama, povrh kojeg u središnjem dijelu prostor zauzima slika s prikazom sv. Jurja, viteza i mučenika, slikara Ivana Krstitelja Rangera. ${ }^{16}$ Ispred slike postavljena su dva svetačka kipa, a uz svaki tordirani stup stoji po jedan evanđelist - sv. Ivan i sv. Marko, koji stoje na konzolama u plitkim nišama, zatvorenima s gornje strane školjkama. Uz vanjske rubove retabla pričvršćena su dekorativna krila $\mathrm{s}$ akantovim lišćem i cvjetovima. U zoni atike u sredini se nalazi slika Blažene Djevice Marije okružena s dva sveca, sv. Stjepanom prvomučenikom i sv. Franjom Ksaverskim. Szabo o oltaru piše svega dvije rečenice: „U svetištu je i

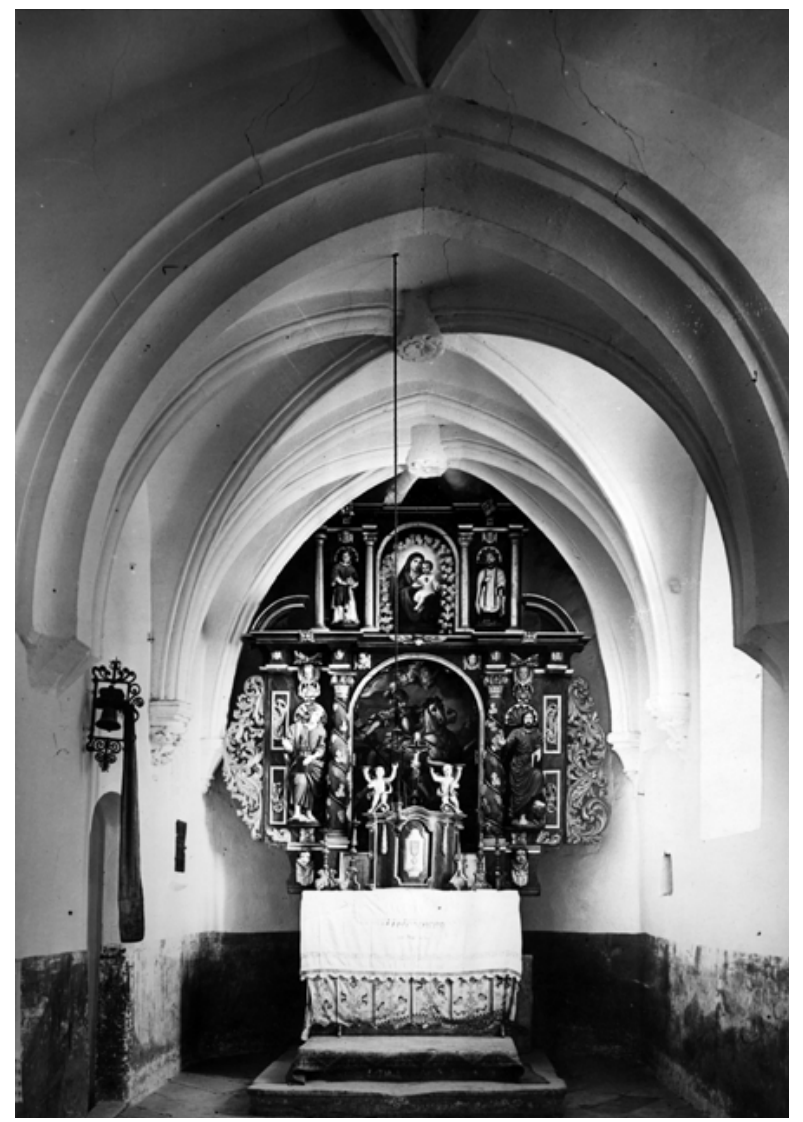

4. Crkva sv. Jurja, unutrašnjost, glavni oltar sv. Jurja iz 17. stoljeća (MKM-FKB, Fotoarhiv HAZU, Gj. Griesbach, 1938., inv. br. 14813) Church of St George, altar of St George, $17^{\text {th }}$ century (MKM-FKB, Croatian Academy of Sciences and Arts, Photo Archive, inv. no. 14813, Gj. Griesbach, 1938)

jedini spomena vrijedni oltar ove crkve posvećen sv. Jurju. Djelo je iz polovine XVII. vijeka, veoma skladno skomponovano, očevidno doneseno s drugoga mjesta, jer je oltaru za volju otrgnut komad rebra na desnoj strani.“17

Ove fotografije prikazuju stanje crkve sv. Jurja koje odgovara radovima koje $u$ spomenici opisuje belečki župnik vlč. Stjepan Tumpić. ${ }^{18}$ Iz spomenice se saznaje kako je župnik o svom trošku nabavio krajem 1885. godine u Beču, iz trgovine Müller sliku Blažene Djevice Marije za veliki oltar, kako bi župljani imali sliku Marije kakva je i u župnoj crkvi te kako je za nju platio 10 forinti. Slika je, uz svečani blagoslov, postavljena na oltar na Januševo 27. prosinca. Nadalje, u spomenici navodi kako te iste godine nabavlja „crninu za mrtvike i svečane requieme za 25 for. ${ }^{\text {“19 }}$ Sljedeći važni radovi na crkvi sv. Jurja, prema spomenici, kreću 1890. godine, kada počinje obnova tornja, za koju je angažiran talijanski „poduzetnik i zidarski majstor Venchiarietti“, i tom je prilikom primijećeno kako krov, tada prekriven hrastovim daščicama (lemeškama) ne valja pa župljani daju prijedlog da će „cielu kapelu izvana i iznutra restaurirati“, za što su i prikupili sredstva. ${ }^{20}$ Rezultat ove akcije bilo je uz obnovljen toranj i novi 
krov od crijepa, obojani unutrašnji zidovi te obnovljeni glavni i jedan bočni oltar. Radovi tu nisu stali - podignut je i novi bočni oltar posvećen Majci Božjoj Lurdskoj, izgrađen od omiljenog kamena vlč. Tumpića, tzv. mačka vađenog na obroncima Ivanščice, povrh naselja Završje. Za ovaj je oltar nabavljen kip Majke Božje Lurdske u Beču od tvrtke Kottal za 36 forinti, zahvaljujući gospođi Franji Jambrečak. $^{21}$

Od 1898. do 1925. godine belečki je župnik vlč. Fran Cesarec, koji u spomenici ističe trošnost crkve sv. Jurja, čak iznosi i bojazan kako bi se mogla srušiti, smatrajući, međutim, kako bi to bilo i najbolje zato što bi se tada mogla načiniti manja kapela u kojoj bi služio misu jer bi to bilo jeftinije od popravka. ${ }^{22}$ Navodi kako se u sv. Jurju dnevno služi misa, kao i nedjeljna „večernjica“, izuzev ako nije važniji blagdan. Ipak vlč. Cesarec odlučuje temeljito obnoviti sv. Jurja te 1905. godine započinje obnovu tornja radi koje se obraća vlasniku belečke gore Židovu Weissu, koji vrlo rado daje potrebito drvo, a za građevinske se radove zadužuje zidar Tagliaretti. Radovi, međutim, ostaju nedovršeni te tako 1910. godine u Belec dolazi Szabo radi pisanja monografije povijesnih spomenika kotara Krapina i Zlatar. Nakon Szabe, u Belec 1938. godine dolazi Gjuro Griesbach zbog fotografiranja kulturno-umjetničkih spomenika u Hrvatskoj, pod vodstvom Artura Schneidera. Prateći fotografije iz tog razdoblja, vide se na glavnom oltaru male promjene - nema dva kipa ispred oltarne slike (sl. 4). Ni na ovoj fotografiji iz 1938. godine antependij nije vidljiv, međutim na fotografijama iz 1942. godine menza oltara ukrašena je antependijem sv. Jurja (sl. 5). U teškim poratnim godinama započinju prvi stručni istraživački radovi u crkvi sv. Jurja koje izvodi 1946. godine konzervator Tihomil Stahuljak. On provodi istraživačke radove na zidovima te otkapa temelje kapele sv. Katarine. Nastavak radova slijedi 1947. godine, kada je uklonjeno pjevalište u zvoniku, oltari u lađi te žbuka na kojoj nema tragova zidnih slika. ${ }^{23}$ Radove završava u prosincu i tada nastaje zasada prvi poznati zapis o antependiju sv. Jurja. U prosincu 1947. godine $u$ Restauratorsku radionicu JAZU stižu dvije slike iz Belca, za koje u kartoteku popravljenih umjetnina Hrvatskog narodnog muzeja za umjetnost $i$ obrt Stanislava Dekleva upisuje slijedeće podatke: slika Sv. Juraj na konju (slika s oltara) i kako piše u dosjeu: „Sv. Juraj s jedne strane, a s druge Smrt“. Za sliku Sv. Juraj na konju navodi kako je bez podokvira, ima jednu veću rupu te je vrlo prljava, a lak matiran. Za antependij navodi sljedeće: „Slika s prednje strane menze. Ulje na platnu. Oslikana s obje strane. Vel. 87 x $140 \mathrm{~cm} .{ }^{24}$ Slika je bez okvira. Puna je sitnih rupa. Boje krakelirane, matirale, vrlo suhe i prljave." Dekleva provodi restauratorske radove na obje slike. U dosjeu slike Sv. Juraj na konju upisuje nakon završenih radova: „Slika je napeta na novi unutarnji okvir. Zakrpana je i očišćena. Krpano mjesto zakitano i retuširano. Slika je natopljena damarom i lanenim uljem“. Za antependij upisuje: „ Slika je napeta među dva nutarnja okvira. Rupe zakrpane i zakitane. Očišćena je i natopljena firnisom.“ ${ }^{25}$

Izgled unutrašnjosti crkve sv. Jurja i glavnog oltara tijekom Stahuljakovih radova 1947. godine, zorno prikazuju fotografije na početku radova te nakon skidanja žbuke s kamena. Na fotografiji iz 1946. godine (sl. 6) te iz 1947. godine (sl. 7) vidljiv je antependij sv. Jurja, kao i oltar na kojem nema nikakvih preinaka u odnosu na stanje 1942. godine, međutim na fotografiji iz 1947. godine (sl. 8), nastaloj nakon radova, vidljiva je demontaža cijele atike, kipova evanđelista kao i oltarne slike, koja je vjerojatno tada bila u restauratorskoj radionici jer su, već 26. prosinca 1947., vraćene na svoja mjesta. ${ }^{26}$ Navedeno potvrđuje i fotografija oltara iz 1948. godine (sl. 9).

Radovi su na zidnim slikama izvođeni i tijekom 50-ih godina prošlog stoljeća, a zatim 70-ih radove u crkvi preuzima Restauratorski zavod Hrvatske (RZH), pa su 1972. godine izvedeni radovi na zidnim slikama i arhitekturi, a predlaže se, u nastavku radova u sljedećoj godini, i dezinsekcija glavnog oltara te utvrđivanje njegovog stanja. ${ }^{27}$ To nije učinjeno zbog uplate sredstava tek na samom kraju godine. $^{28}$

Iste godine o oltaru sv. Jurja piše Doris Baričević ${ }^{29}$ koristeći fotografiju Gjure Griesbacha. Ona ga smješta u posljednje desetljeće 17 . stoljeća, detaljnije proučava podatke vizitacije iz 1708. godine, putem kojih saznaje kako je u centralnom dijelu nekad bio kip sv. Jurja, dok je umjesto slike Bogorodice na atici nekad stajao Spasitelj između sv. Ignacija i sv. Ksavera. Nadalje, konstatira kako atika s kipovima sv. Stjepana i sv. Franje Ksaverskog nije vraćena na svoje izvorno mjesto te da su kipovi pohranjeni na župnom dvoru. Baričević navodi kako su tamo pohranjene i skulpture apostola Petra i Pavla, nešto većih dimenzija od skulptura s atike, koje potječu s nekog od porušenih oltara, najvjerojatnije s oltara sv. Barbare koji, prema vizitaciji iz 1729. godine, ima istoimene kipove. Međutim, ona ne spominje Szabine fotografije na kojima je vidljivo da su navedene skulpture svojedobno bile smještene na glavnom oltaru ispred oltarne slike. Sliku s glavnog oltara datira u 18. stoljeće, no nažalost o antependiju ne piše ništa. Pregledom Osobnog fonda Doris Baričević, koji se čuva u Nadbiskupijskom arhivu u Zagrebu, a odnosi se na crkvu sv. Jurja, uočene su bilješke koje su poslužile za pisanje navedenog priloga. Tamo je i Griesbachova fotografija i fotografija K. Klaića s kipovima sv. Petra i Pavla, te sv. Stjepana i sv. Franje Ksaverskog snimljenima u župnom dvoru 1968. godine. ${ }^{30} \mathrm{Na}$ poleđini ove fotografije uz naziv lokaliteta, dopisana je bilješka „P. i P iz ž dvora - sada u dvorskoj kapeli u D. Bedekovčini“ - što je bez sumnje korisna informacija jer tijek ovog premještaja nije bio poznat. Pregledom arhivskih fotografija koje su snimljene tijekom radova Restauratorskog zavoda Hrvatske, vidi se da je 1972. godine antependij 


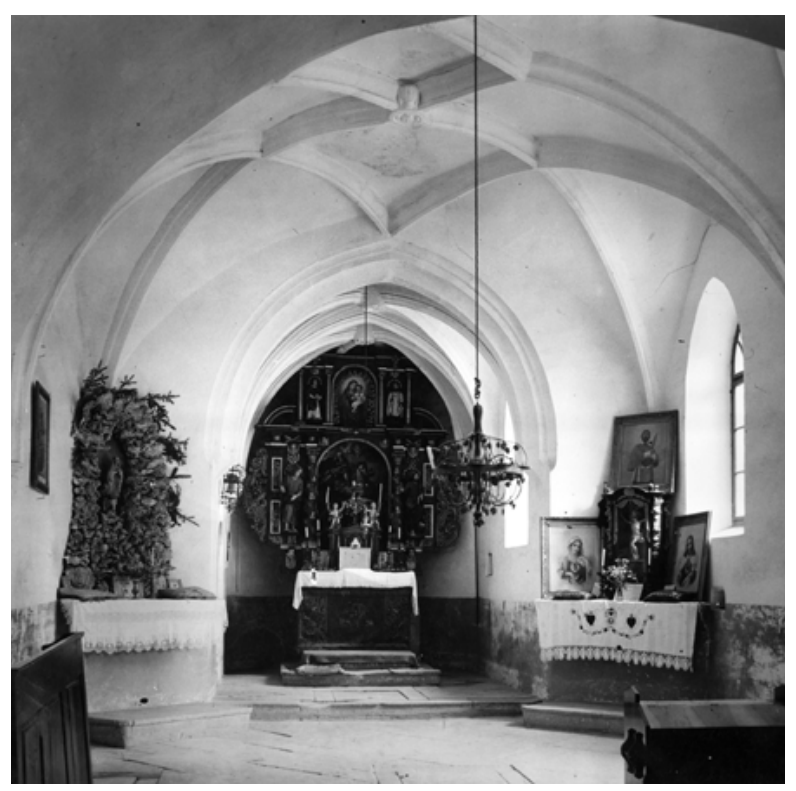

5. Crkva sv. Jurja, pogled prema svetištu s tri oltara (MKM-FKB, snimka: Fotozadruga, 1942., inv. br. 5352)

Church of St George, sanctuary with three altars (MKM-FKB, inv. no. 5352, Fotozadruga, 1942)

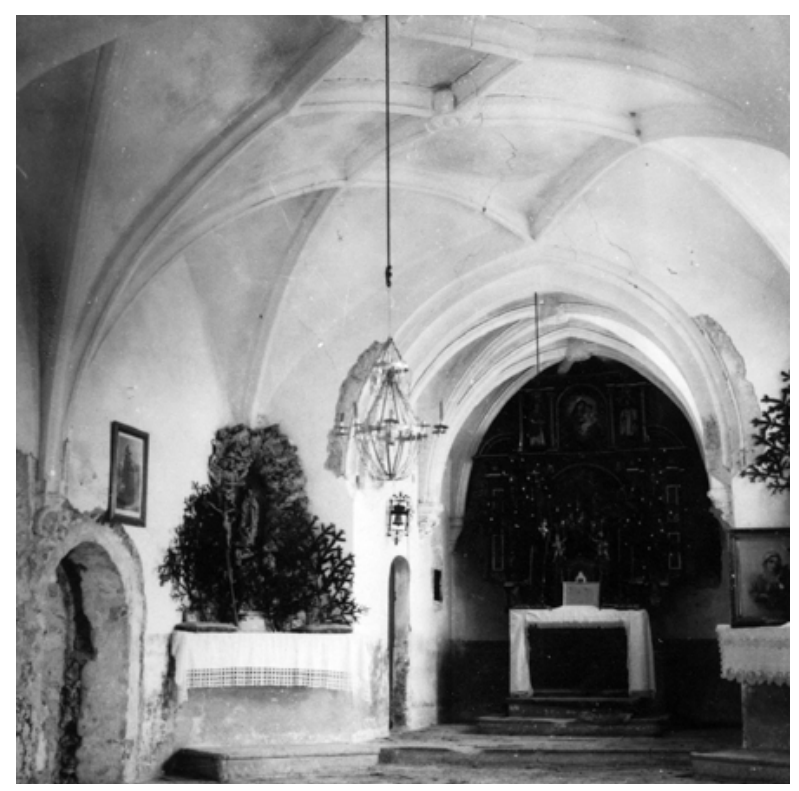

6. Crkva sv. Jurja, svetište i pokrajnji oltar Gospe Lurdske gledano prema sjeveroistočnom kutu. Započeto otvaranje vratiju na sjevernoj strani lađe (MKM-FKB, snimka: D. Kečkemet, 1946., inv. br. 5355)

Church of St George, sanctuary and the side altar of Our Lady of Lourdes from the northeast corner, work having started on opening the door on the north side of the nave (MKM-FKB, inv. no. 5355, D. Kečkemet, 1946)

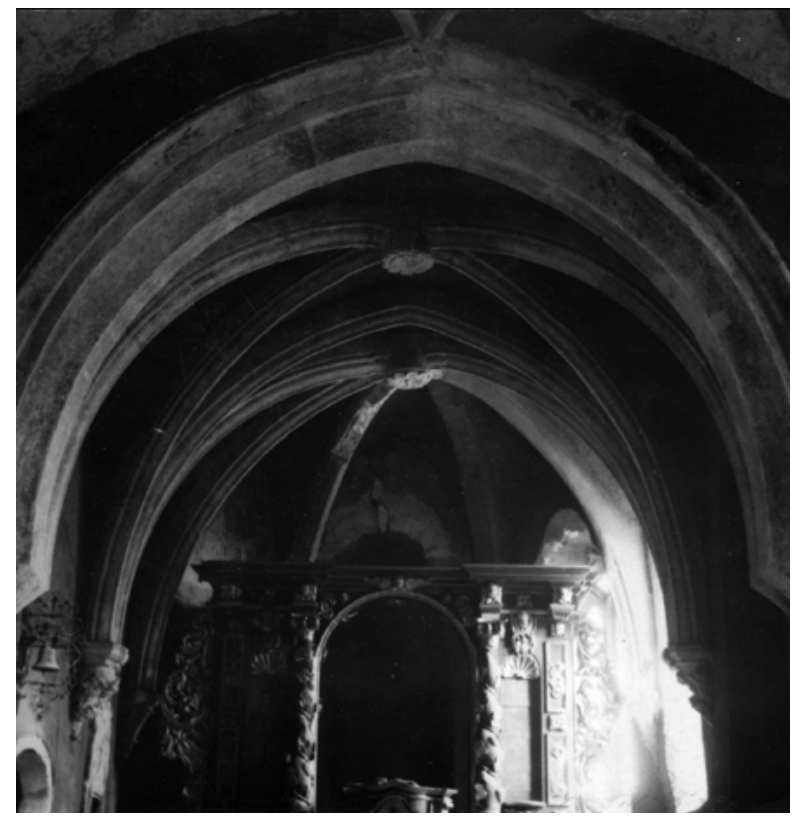

8. Crkva sv. Jurja, svetište nakon skidanja žbuke s kamena (MKMFKB, snimka: T. Dabac, 1947., inv. br. 5377)

Church of St George, sanctuary after removing the plaster from the stone (MKM-FKB, inv. no. 5377, T. Dabac, 1947)

i u 80-ima, bilo je otkriće sarkofaga u tornju crkve, 1989. godine, prilikom otkopavanja temelja (sl. 11). S obzirom na cjelokupnu slojevitost i vrijednost crkve sv. Jurja, Resta-

uratorski zavod Hrvatske 1993. godine izrađuje projekt na oltaru (sl. 10), no na fotografijama iz 1983. godine ga više nema. Radovi Restauratorskog zavoda Hrvatske tijekom 70-ih su godina bili fokusirani na arhitekturu i zidne slike, ${ }^{31}$ a vrhunac dugotrajnih radova, koji su se nastavili 


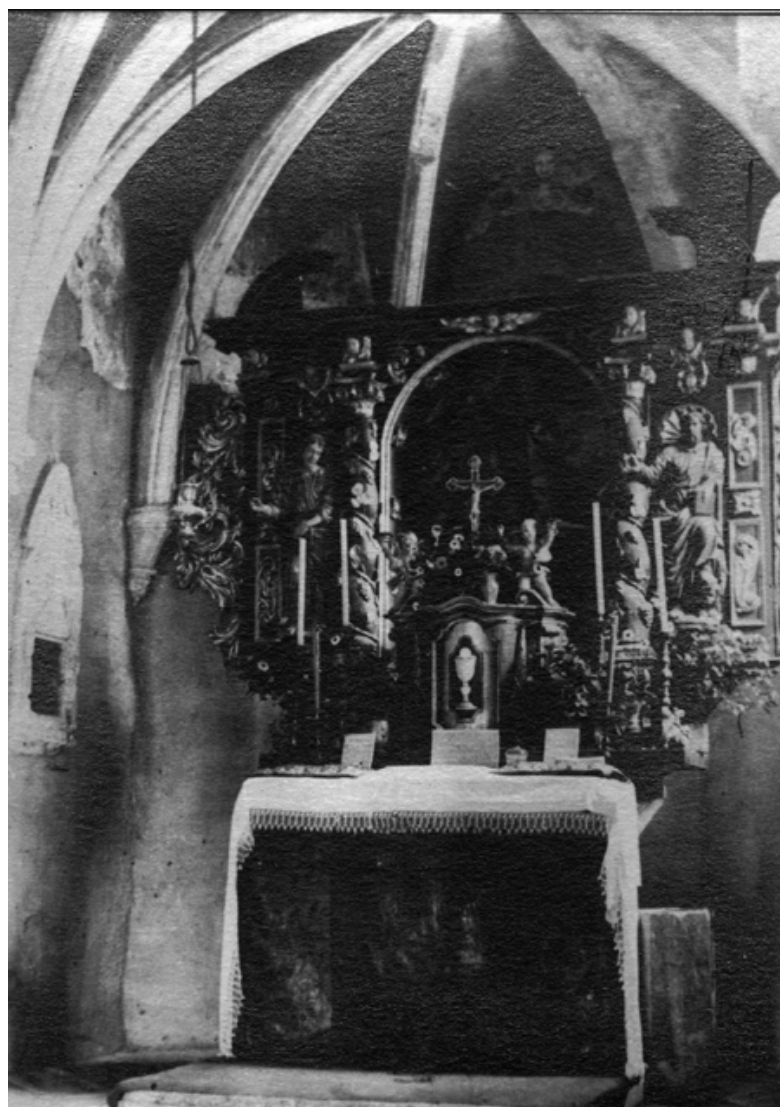

9. Crkva sv. Jurja, glavni oltar sv. Jurja nakon popravka (MKM-FKB, snimka: Z. Munk, 1948., inv. br. 6067)

Church of St George, altar of St George after repairs (MKM-FKB, inv. no. 6067, Z. Munk, 1948)

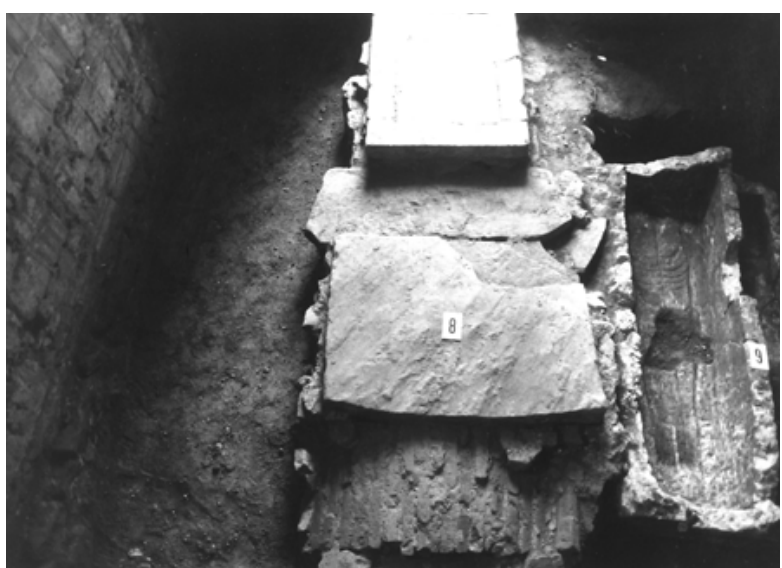

11. Crkva sv. Jurja, sarkofag, tijekom istraživačkih radova (arhiva HRZ-a, snimka: D. Miletić, 1989.)

Church of St George, sarcophagus, during research (HRZ Photo Archive, D. Miletić, 1989)

prezentacije $u$ kojem je odlučeno kako se ostaci postojećeg oltara sv. Jurja ne vraćaju na prijašnje mjesto jer zaklanjaju zaključak gotičkog svetišta i ujedno smanjuju količinu svjetlosti u crkvi. U novonastaloj državi mijenja se način financiranja radova - sredstva za obnovu crkve Ministarstvo kulture upućuje na općinu. Budući da

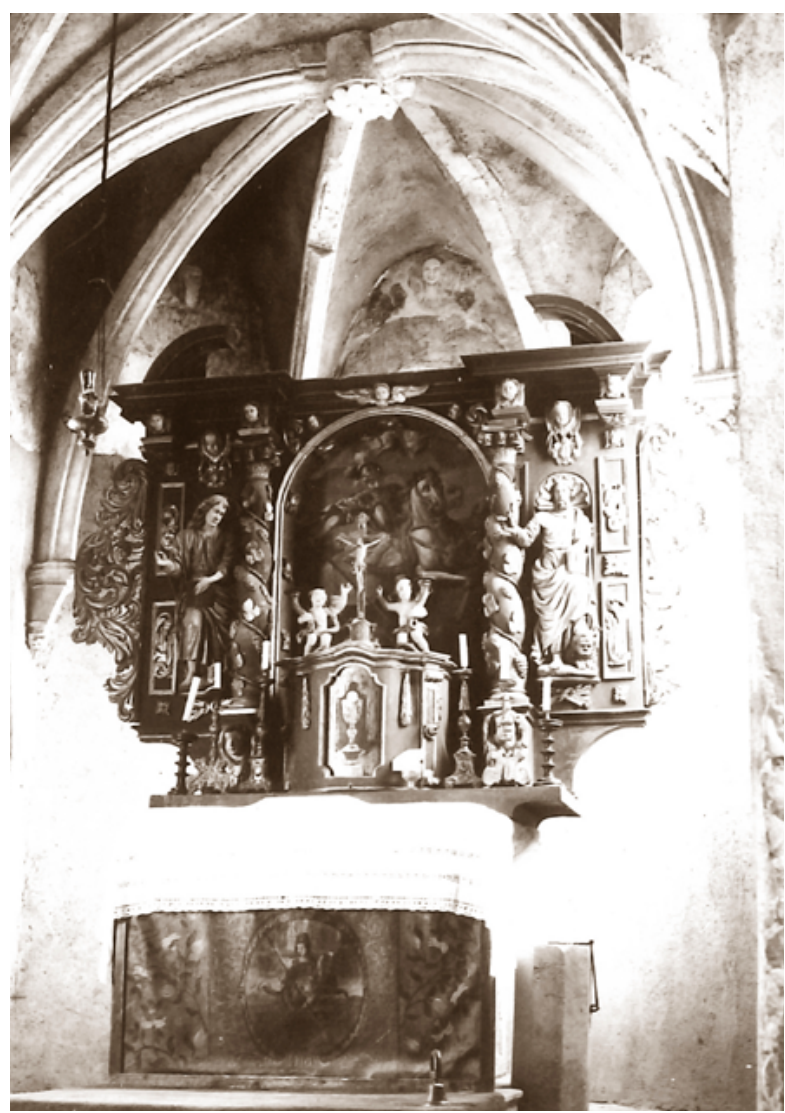

10. Crkva sv. Jurja, oltar sv. Jurja, pogled iz lađe (arhiva HRZ-a, snimka: I. Maroević, 1972.)

Church of St George, altar of St George, view from the nave (HRZ Photo Archive, I. Maroević, 1972)

općina Zlatar nije davala obavezni dio u iznosu od $30 \%$ na državna sredstva, krajem 90-ih Hrvatski restauratorski zavod, odnosno služba zaštite, gubi nadzor nad vođenjem radova zbog neuplaćenih općinskih sredstava. To je rezultiralo nestručnim rješenjima, poput sjajno poliranog poda i halogenih svjetiljki u gotičkom svodu, čime ni župljani 


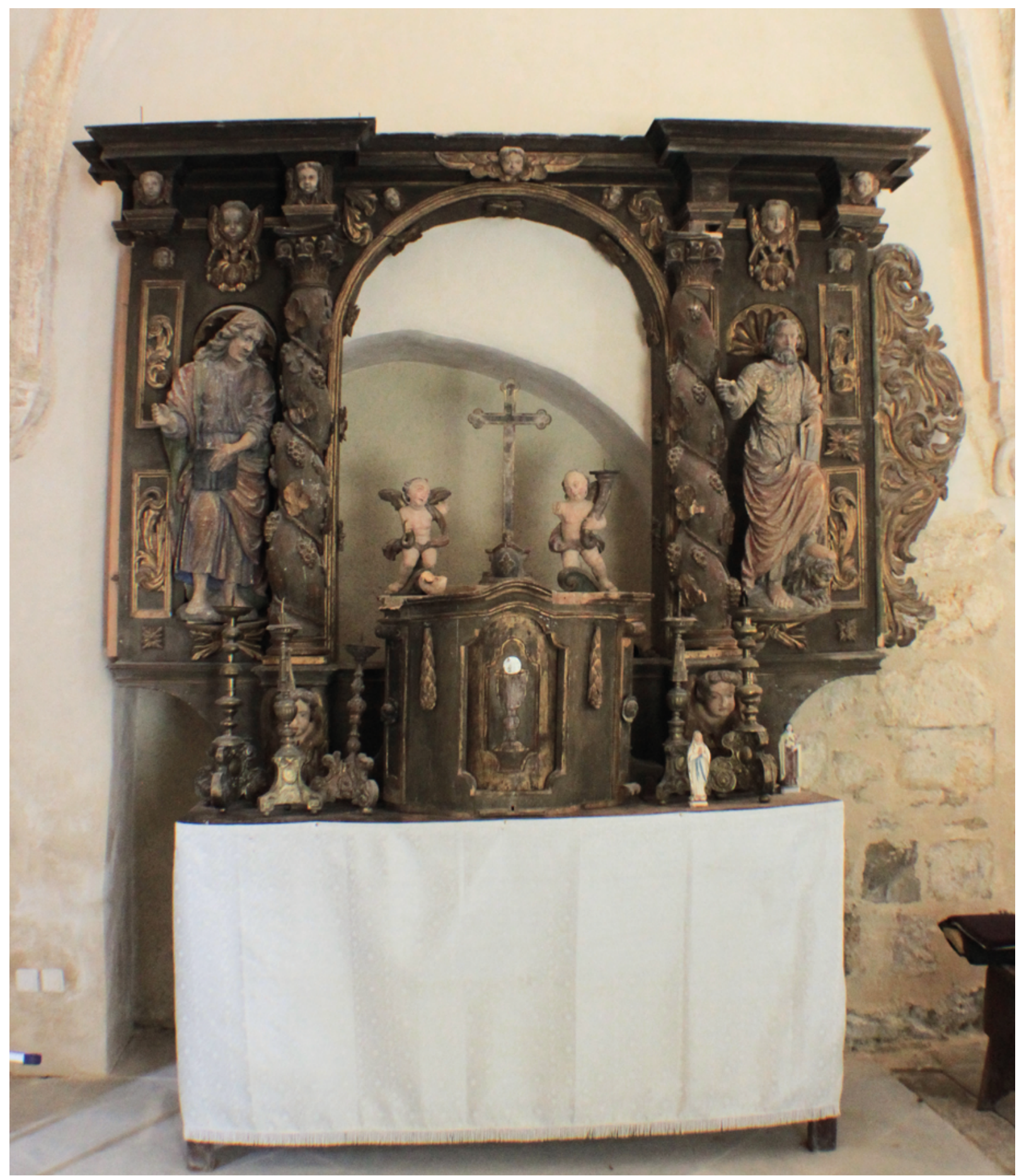

12. Crkva sv. Jurja, oltar sv. Jurja (arhiva HRZ-a, snimka: I. Sambolić, 2013.)

Church of St George, altar of St George (HRZ Photo Archive, I. Sambolić, 2013)

nisu bili zadovoljni. ${ }^{32}$ Nakon kritične reakcije struke, izvedeni su radovi koji su bili u skladu s ciljevima projekta prezentacije iz 1993. godine. Sad već znatno okrnjeni oltar, bio je smješten na stol uz sjeverni zid u lađi sve do 2018. godine kada su na njemu započeli konzervatorskorestauratorski radovi u privatnoj radionici (sl. 12). ${ }^{33}$ Slika s oltara sv. Jurja, restaurirana je 1999. godine u Hrvatskom restauratorskom zavodu, prije izložbenih aktivnosti Muzeja Hrvatskog zagorja te je trenutno izložena u crkvi na štafelaju. Višegodišnji radovi na arhitekturi i zidnim slikama završeni su i prezentirani u sklopu Europske godine kulturne baštine 2018. godine.

\section{Obostrano slikan antependij sv. Jurja, nepoznati autor, ulje na platnu, prva pol. 18 stoljeća}

Potraga za informacijama o porijeklu antependija dala je skromne rezultate, a možda bi i sam antependij bio zaboravljen da nije pronađen $u$ sobi na prvom katu župnog 


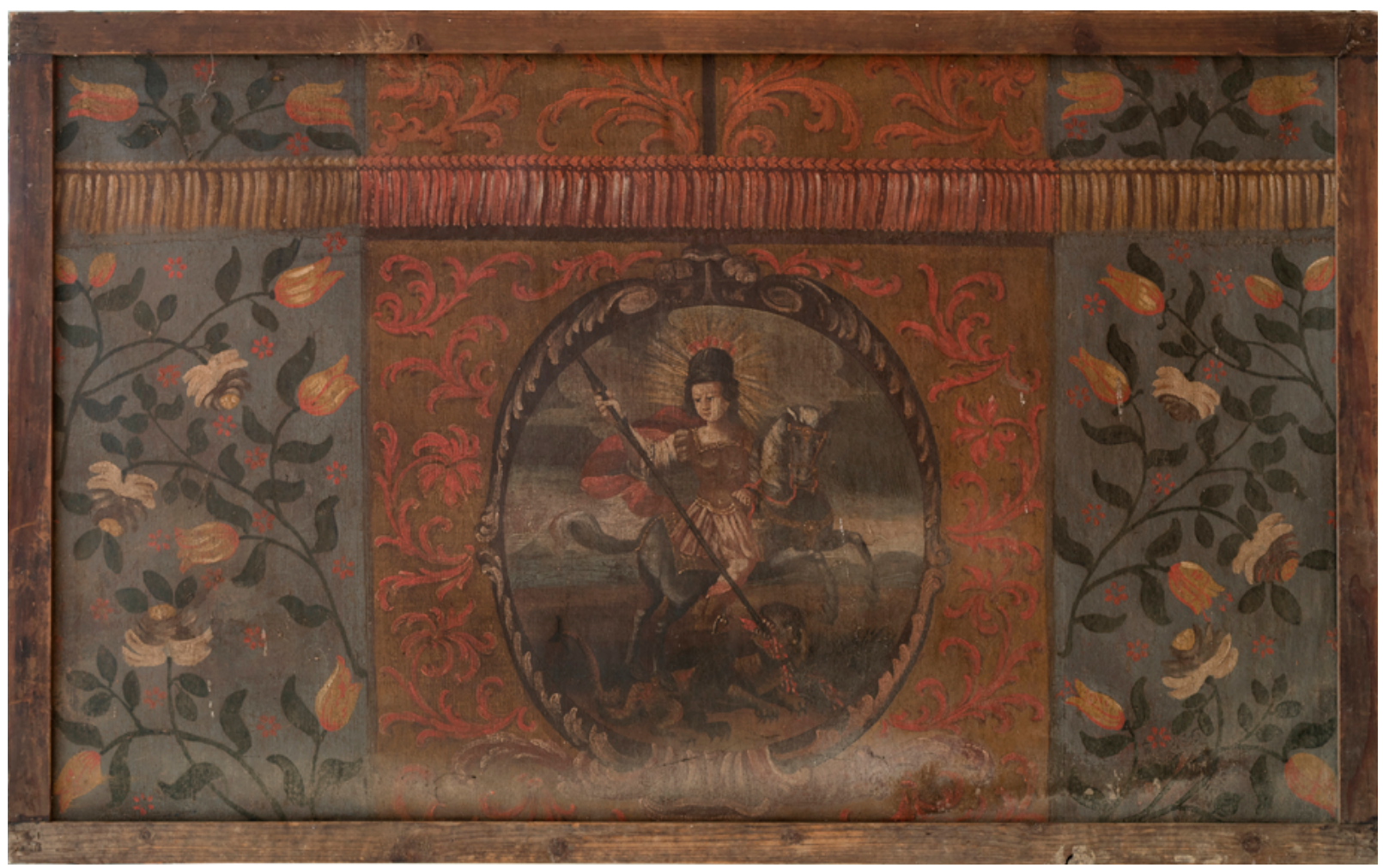

13. Crkva sv. Jurja, antependij sv. Jurja, prije radova (arhiva HRZ-a, snimka: N. Oštarijaš, 2018.)

Church of St George, antependium of St George, condition before conservation (HRZ Photo Archive, N. Oštarijaš, 2018)

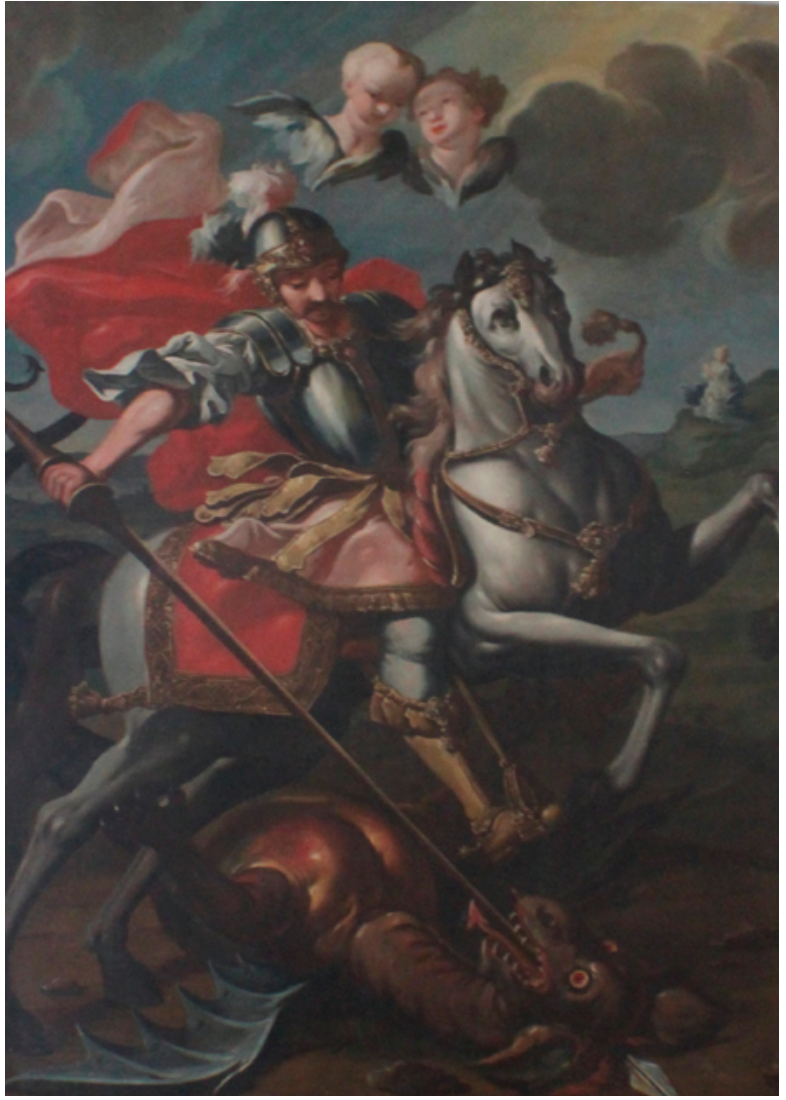

14. Crkva sv. Jurja, Ivan Ranger, Sv. Juraj u borbi sa zmajem, 1740. (snimka: I. Sambolić, 2014.)

Church of St George, Johann Baptist Ranger, Saint George Slaying the Dragon, 1740 (I. Sambolić, 2014)

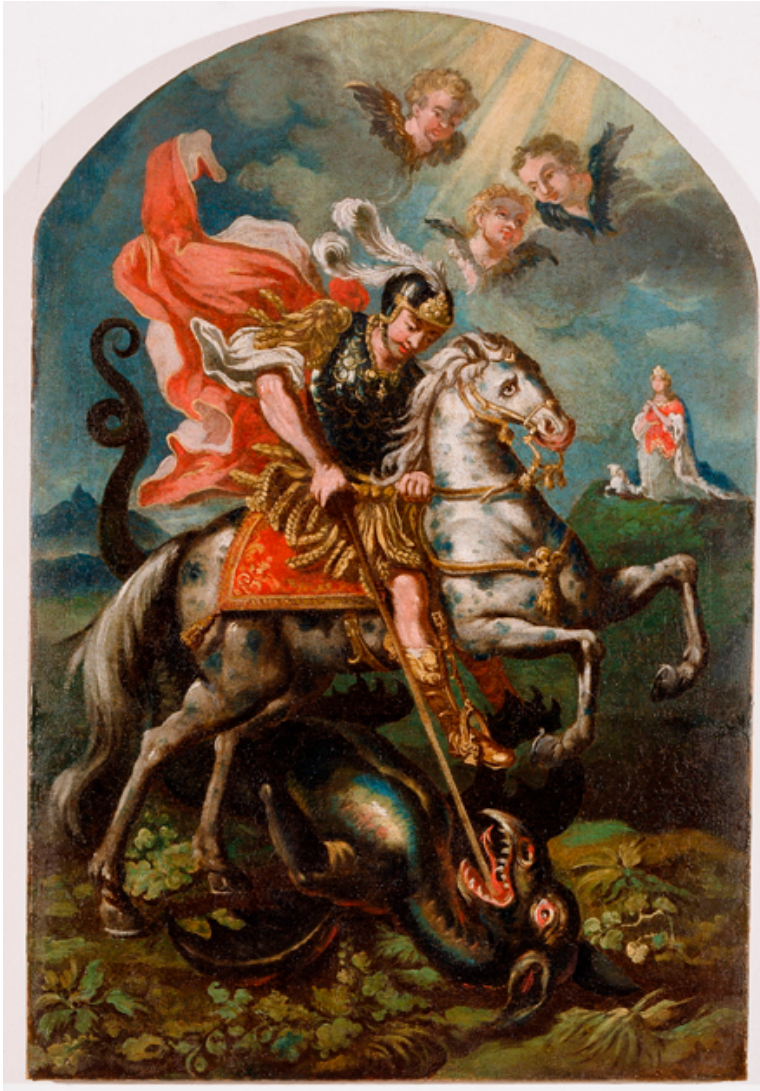

15. Purga Lepoglavska, kapela sv. Jurja, Ivan Ranger?, Sv. Juraj, oko 1750. (arhiva HRZ-a, snimka: V. Barac, 2000.)

Purga Lepoglavska, chapel of St George, Ivan Ranger?, St George, c. 1750 (HRZ Photo Archive, V. Barac, 2000) 


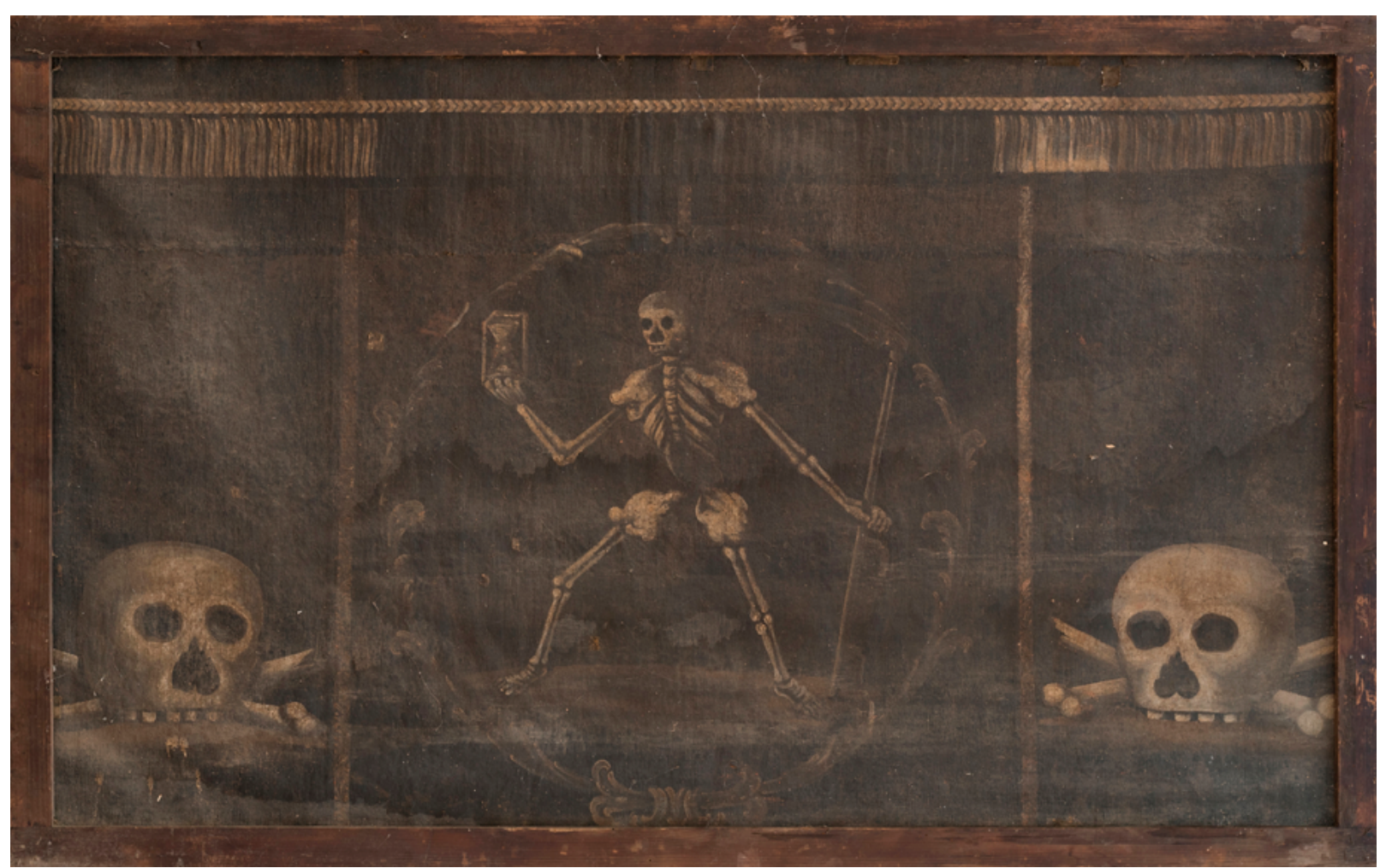

16. Crkva sv. Jurja,antependij sv. Jurja, memento mori na stražnjoj strani, prije radova (arhiva HRZ-a, snimka: N. Oštarijaš, 2018.) Antependium of St George, memento mori on the back, condition before conservation (HRZ Photo Archive, N. Oštarijaš, 2018)

dvora tijekom izrade župnog imovnika 2016. godine. ${ }^{34}$ Zatečen je u vrlo zapuštenom stanju. S obzirom na općenito malobrojne primjere dvostrano slikanih slika, uvršten je u programsku djelatnost Hrvatskog restauratorskog zavoda u 2018. godini. Cilj je radova na antependiju bio njegovo ponovno vraćanje na oltar, s omogućenim obostranim sagledavanjem prema potrebi. Na taj način bi se dovršili višegodišnji konzervatorsko-restauratorski radovi u crvi sv. Jurja.

S prednje strane antependij je vertikalno podijeljen na tri registra (sl. 13). U gornjem dijelu naslikan je rub stolnjaka s resicama, jednako kao i na stražnjoj strani antependija. U središnjem je dijelu prikazan sv. Juraj, prema vrlo čestom predlošku koji svoje uporište ima u legendi opisanoj u djelu Legenda aurea Jakoba od Voragine iz 13. stoljeća. Legenda govori o zmaju koji je živio u močvari kod grada Silene u tadašnjoj Palestini i kome su žitelji svaki dan davali po dvije ovce, a kad je nestalo ovaca morali su mu dati mladića ili djevojku, stoga je jednog dana došao red i na kraljevu kćer. No, obraćeni rimski vojnik Juraj kopljem probada zmaja i spašava kraljevu kćer, a zahvaljujući tome, puk prelazi na kršćanstvo. ${ }^{35}$ Isti je motiv prikazan i na slici s retabla koja je pripisana Rangeru (sl. 14), a koja je najvjerojatnije bila izrađena tijekom oslikavanja zidova crkve sv. Marije Snježne, za što su između 1739. i 1742. godine bili angažirani pavlini ${ }^{36}$ Sličan primjer pavlinske škole nalazi se u Purgi kod Lepoglave, slika je također pripisana Rangeru, a datirana je u vrijeme oko 1750. godine (sl. 15). ${ }^{37}$ Usporedbom slikareve tehnike i rukopisa očito je da prikaz sv. Jurja na antependiju itekako zaostaje u vještini i kvaliteti za onim koji je pripisan Rangeru. Prikaz legende o sv. Jurju na antependiju smješten je u ovalnoj kartuši okruženoj viticama, $u$ registru koji je ispunjen crvenim motivom akanta na oker pozadini, te s lijeve i desne strane s vegetabilnim motivom s cvijećem, što ne odudara od dekoracije tipične za antependije nastale $u$ 18. stoljeću na području kontinentalne Hrvatske. Baričević smješta oltar u posljednje desetljeće 17 . stoljeća, ${ }^{38}$ što može pobliže odrediti dataciju antependija. Način oblikovanja akanta koji je prikazan na antependiju, čest je na oltarima sjeverozapadne Hrvatske, nastalima u prvoj četvrtini 18. stoljeća. ${ }^{39}$ Slikarevi su potezi vrlo široki i jednostavni, a na pojedinim mjestima vidljiv je donji slikani sloj s drugačijom ornamentikom. Na stražnjoj se strani nalazi prikaz prolaznosti života (memento mori) na crnoj pozadini, koja je podijeljena na tri registra (sl. 16). Memento mori se kao ikonografska tema javlja u kasnom srednjem vijeku, a na njezin je nastanak važan utjecaj imala epidemija kuge koja je opustošila mnoge regije i gradove Europe u tom razdoblju. Najtragičnija bila je Druga pandemija ili Crna smrt koja je završila krajem 17. stoljeća, te koja je, na svom vrhuncu u 14. stoljeću usmrtila oko dvije trećine europskog stanovništva. ${ }^{40}$

$\mathrm{Na}$ antependiju je prikazan Smrt-kosac, koji se u ikonografiji smješta u grupu prikaza koji žele naglasiti da je 
smrt nenadana, univerzalna i sverazorna, a tu činjenicu dodatno naglašava pješčani sat koji kostur drži u desnoj ruci. ${ }^{41}$ Smrt-kosac smješten je u središnjem polju unutar okvira ukrašenog viticama. S lijeve i desne strane flankira ga po jedna lubanja s dvije prekrižene kosti. ${ }^{42}$ Iako se ovaj antependij ne ističe po likovnoj kvaliteti, ipak je, zajedno s cijelim oltarom, ključan za razumijevanje kontinuiteta uređenja unutrašnjosti jedne od najstarijih crkava Hrvatskog zagorja. Nejasna je, međutim, svrha ovakvog dvostrukog prikaza, no potraga za odgovorima krenula je istovremeno s izvođenjem cjelovitih konzervatorskorestauratorskih radova.

\section{Konzervatorsko-restauratorski radovi na antependiju sv. Jurja}

Antependij je zatečen s vidljivim deformacijama platnenog nosioca, zbog dotrajalog podokvira koji ujedno ima funkciju ukrasnog okvira. Slikana je površina s obje strane bila prekrivena slojem prašine i alteriranog laka koji se upio $u$ sliku, pa je površina bila izrazito matirana. Krakelire su vrlo sitne na obje strane slike. U donjim su zonama bila vidljiva zabijeljena zbog djelovanja vlage na završni premaz. S obje su strane bili vidljivi kapljičasti ostaci voska od svijeća, što sugerira da se antependij okretao tijekom određenih obreda. Na slikanom sloju bila su vidljiva sitnija mehanička oštećenja i ogrebotine, kao i manja područja s otpalom preparacijom, te preslici na strani na kojoj je prikazan sv. Juraj. Na obje su strane slike bile su vidljive intervencije iz 1947. godine, koje su s vremenom postale još uočljivije. ${ }^{43}$ Sa stražnje strane, na područja mehaničkih oštećenja, nalazile su se voskom učvršćene pamučne zakrpe, tonirane crnom bojom radi što boljeg uklapanja u tamnu pozadinu slike.

Nakon suhog čišćenja obje strane antependija i uklanjanja neadekvatnih pamučnih zakrpa, izvedena je demontaža prednjeg dijela drvenog okvira/podokvira (na strani s prikazom sv. Jurja), čime se dobio uvid $u$ stanje rubova platna i u način napinjanja slike. Antependij nema sačuvanih izvornih rubova, a njegov se format mijenjao, te su rezanjem stradali rubni dijelovi slikanog sloja. Napinjanje na okvir tijekom radova izvedenih 1947. godine, izvedeno je tako da su se čavlići probijali kroz sliku na stražnju letvicu okvira. Uočene su starije rupice od čavlića, koje su u većem broju bile prisutne uz gornji rub, a zatim i u uglovima, po čemu se zaključuje da je okvir bio učvršćivan na menzu u više navrata u određenom periodu. Rezultat analize mikropresjeka (sl. 17) ukazuje da je tamnocrvena preparacija po sastavu ista na obje strane antependija ${ }^{44}$ te da je kit iz 1947., koji je koristila Dekleva, na bazi voska.

Čišćenje antependija provedeno je tako da se prvo uklanjao sloj upijene prašine i prljavštine pomoću puferiranih otopina s dodatkom tenzida, dok se završni premaz uklanjao emulzijom ulja u vodi. Također su uklonjeni ostaci

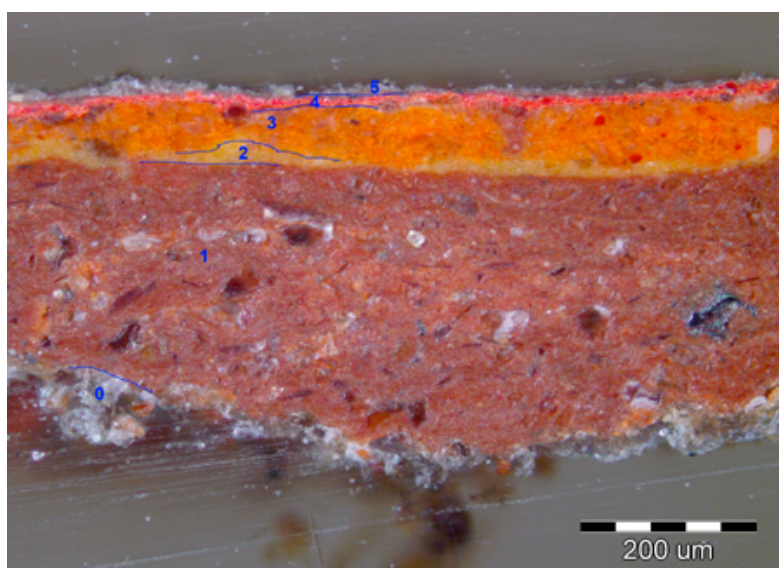

17. Mikrofotografija poprečnog presjeka na kojoj se vidi tonirana preparacija (arhiva HRZ-a, snimka: M. Fabečić, 2018.) Micrograph of a cross-section showing the tinted preparation (HRZ Photo Archive, M. Fabečić, 2018)

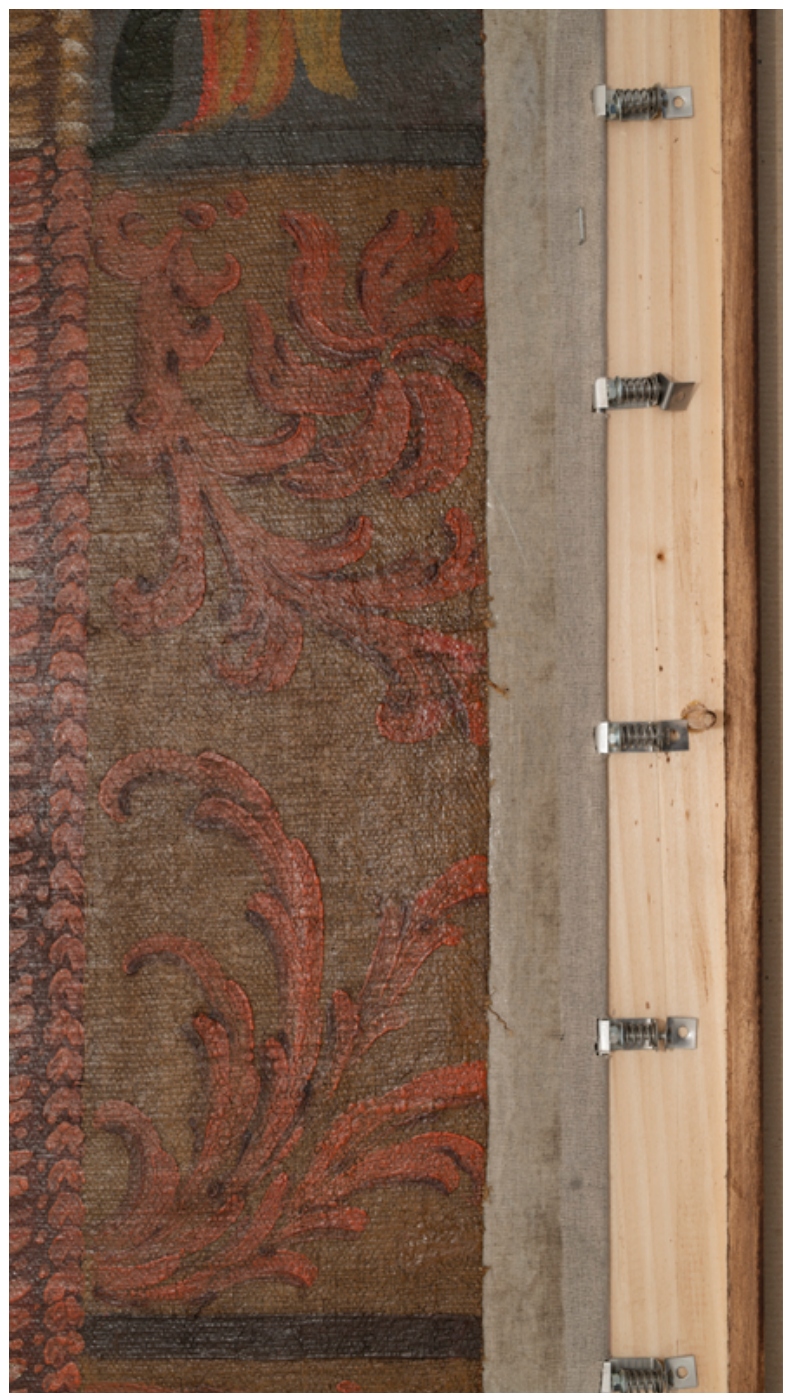

18. Metoda napinjanja antependija pomoću sustava elastičnih opruga, detalj tijekom radova (arhiva HRZ-a, snimka: N. Oštarijaš, 2020.)

Method of tensioning the antependium using a system of elastic springs, detail during conservation (HRZ Photo Archive, N.

Oštarijaš, 2020) 


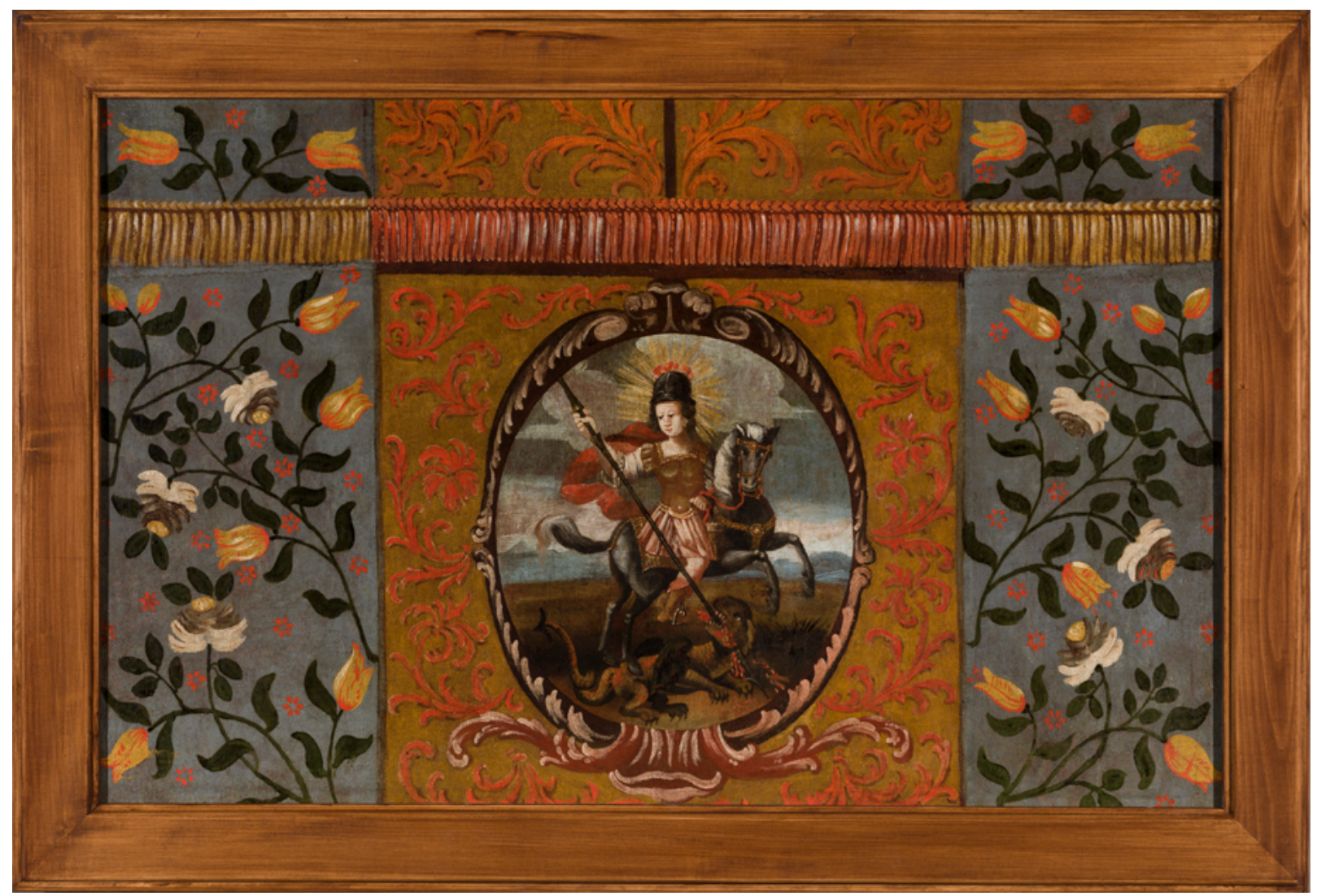

19. Antependij sv. Jurja, nakon radova (arhiva HRZ-a, snimka: N. Oštarijaš, 2020.)

Antependium of St George, condition after conservation (HRZ Photo Archive, N. Oštarijaš, 2020)

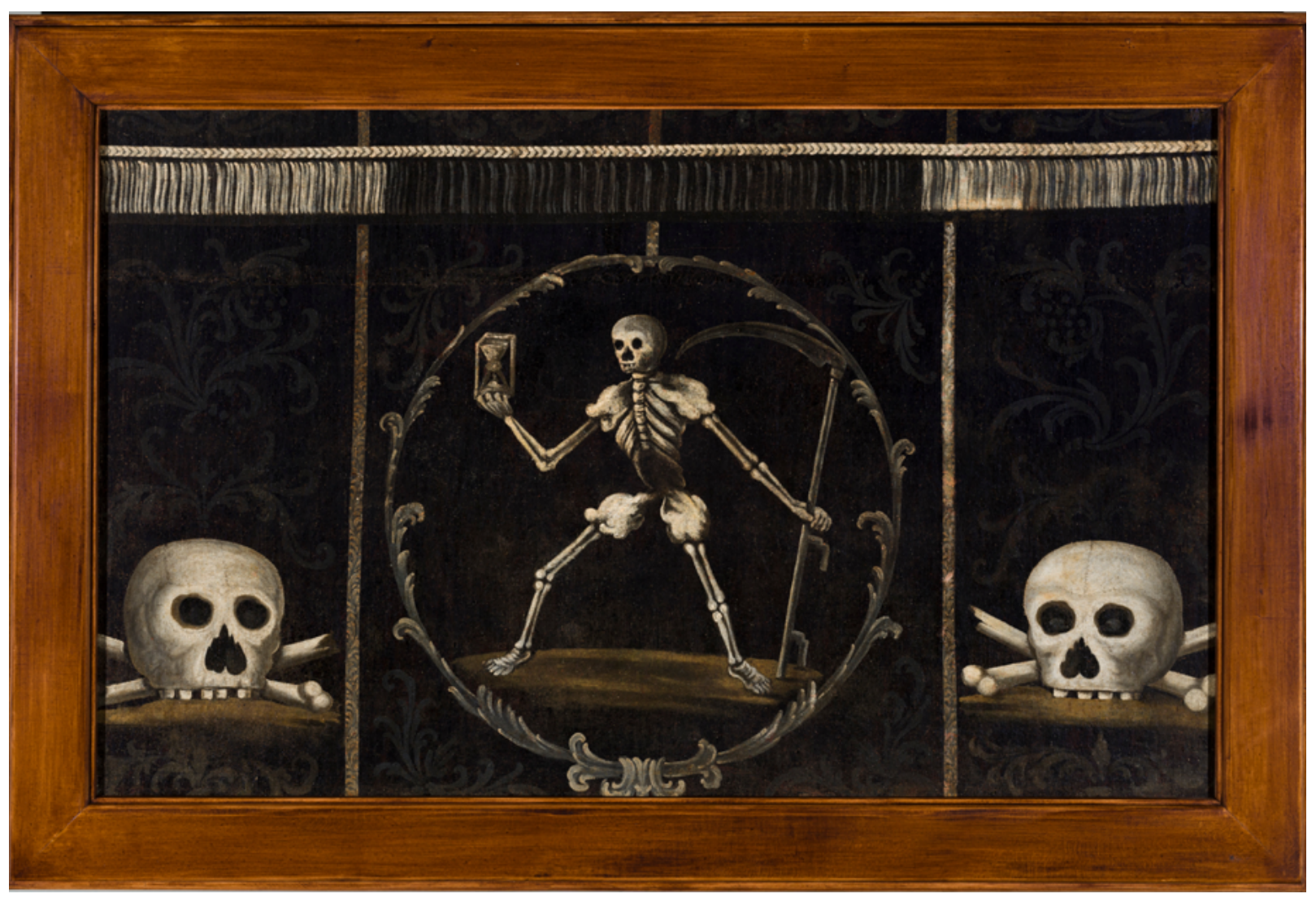

20. Antependij sv. Jurja, memento mori na stražnjoj strani, nakon radova (arhiva HRZ-a, snimka: N. Oštarijaš, 2020.)

Antependium of St George, memento mori on the back, condition after conservation (HRZ Photo Archive, N. Oštarijaš, 2020) 
voska od svijeća te neadekvatni zakiti i preslici. Nakon ravnanja deformacija nosioca, na područja su perforacija umetnute platnene intarzije, jednake gustoće tkanja kao i originalno platno, te niti. Ova faza radova iziskivala je posebnu pažnju jer su se niti novog platna povezivale ispod slikanog sloja i osnove, i to s obje strane, s ciljem što boljeg pripasivanja, koje je nužno za uspješnu prezentaciju slikane površine s obje strane. Gubici u sloju osnove nadomješteni su pomoću toniranog kita, a potom je izvedeno podlaganje retuša gvašem. Nakon podlaganja retuša, pristupilo se pripremnim radovima čija je svrha napinjanje slike na posebno konstruiran podokvir, koji ujedno ima funkciju ukrasnog okvira. Ova je faza radova izvedena tako da su, najprije na strani s prikazom memento mori, učvršćene trake lanenog platna (strip-lining) te se zatim antependij napeo na pomoćni podokvir s mogućnošću podešavanja napetosti, nakon čega je izveden završni retuš pomoću smolnih boja i lakiranje. Slika se potom napela na novi podokvir/ukrasni okvir pomoću sustava elastičnih opruga koje su smještene unutar šupljine ukrasnog okvira (sl. 18). ${ }^{45}$ Ovom metodom napinjanja ostvaren je cilj - omogućena je jednolika napetost slike, a ujedno je moguće cjelovito sagledavanje antependija s obje strane (sl. 19 i 20). Nakon napinjanja, antependij se pohranio u čuvaonicu HRZ-a. Montaža antependija planirana je nakon završetka konzervatorsko-restauratorskih radova na pripadajućem oltaru, koji su u tijeku.

\section{Kontekst i svrha prikaza motiva memento mori na stražnjoj strani antependija}

Usporedno s konzervatorsko-restauratorskim radovima na antependiju sv. Jurja tekla je potraga za odgovorima svrhe dvostrukog prikaza, naročito što se tiče motiva memento mori. Prednja strana je sasvim jasna, prikazuje sv. Jurja - nekadašnjeg titulara crkve i župe te vrlo omiljenog sveca koji je 23. travnja 303. godine umro mučeničkom smrću u Palestini kao rimski vojnik i kršćanin. Za svoga su ga zaštitnika uzeli srednjovjekovni vitezovi i križari, zaštitnik je konja, ratarstva i zelenila, a posebno mu se pripisivala zaštita od zaraznih bolesti, kuge i rata. Slave ga podjednako kršćani, muslimani i Romi, posebno na Đurđevdan. ${ }^{46}$ Ništa neuobičajeno nema $u$ tome da antependij sa svecem bude postavljen na menzu oltara istog sveca, i to u crkvu čiji je taj svetac titular.

Međutim, pogled na stražnju stranu otvara puno pitanja, prije svega zbog čega je izabran upravo taj motiv i koja je bila svrha tog prikaza sa stražnje strane? Memento mori, kao podsjetnik na neminovno, predočen je na antependiju prikazom Smrti-kosca, koji je u ikonografiji smrti uvršten u skupinu prikaza u kojoj su i Smrt-strijelac, Ples mrtvaca, Imago mortis i Trijumf smrti, skupinu koja upozorava da je smrt nenadana.

Smrt je u kršćanskoj eshatologiji prva od posljednje četiri stvari, a slijede sud, raj i pakao. Prema Katekizmu katoličke crkve, smrću se odjeljuje duša od tijela, nakon čega se tijelo raspada: „... dok besmrtna duša ide $u$ susret Božjem sudu i čeka da se ponovno sjedini s tijelom, kada o ponovnu Gospodnjem dolasku preobraženo uskrsne. Shvatiti kako će se uskrsnuće ostvariti nadilazi naše predodžbe i naše shvaćanje.“47 Smrt se može tumačiti još kao kazna za grijeh, ${ }^{48}$ s primjerom iz Knjige postanka gdje je Bog rekao Adamu (Post 2,17): „Samo s drva spoznaje dobra i zla ne jedi! Jer čim bi s njega jeo, morao bi umrijeti.“

Razmišljanje o smrti, kao kazni za grijeh, bilo je vrlo prisutno, osobito zbog epidemije kuge, u srednjem vijeku kada su se razvijali likovni predlošci vezani uz smrt. Nasuprot smrti je vječni život i Isus Krist, koji je smrt pobijedio, ${ }^{49}$ što se u kršćanstvu manifestira $u$ potrebi obraćenja za spas duše od smrti pri čemu su prikazi zastrašujuće smrti bili više nego uspješno didaktičko sredstvo. Popularni je barokni prinos toj temi u literarnolikovnom obliku emblema bio trodijelni moralizirajući priručnik iz 1682. godine Theatrum humanæe mortis tripartitum Johanna Weicharda Valvasora, u kome su oživjeli brojni stariji motivi ikonografije smrti i pouke vezane za te ikonografske zadatke, ${ }^{50}$ a značajna je i pojava motiva $u$ stucco-dekoraciji kapele sv. Josipa iz 1692. godine $u$ franjevačkoj crkvi sv. Ivana Krstitelja u Varaždinu. ${ }^{51}$

Kod antependija, koji prije svega pripada liturgijskoj opremi oltara, u belečkom je slučaju memento mori prikazan sa stražnje strane, zbog čega bi mu didaktička svrha bila minimalna. U nastojanjima da se donekle dokuči u kojem razdoblju je antependij bio u upotrebi i na koje sve načine, obavljeni su razgovori sa starijim župljankama ${ }^{52}$ koje su bile aktivne $u$ župi sredinom prošlog stoljeća, te se tada došlo do novih zanimljivih spoznaja. Iako im antependij nije ostao u sjećanju, u razgovorima se saznalo za obred koji se obavljao, češće u crkvi sv. Jurja, a ponekad i u crkvi sv. Marije Snježne. Postojao je, naime, običaj da se za pokojnika, na godišnjicu njegove smrti ili kada bi ga se sanjalo, što se smatralo znakom da duša nije našla spokoj, služi rekvijem ili „mrtviečka meša“, „črna meša“. Za takvu bi se misu se ispred oltara postavio „skolk“ (katafalk, odar) s praznim lijesom prekrivenim crnom tkaninom, a na mjestu gdje je trebala biti glava pokojnika postavila bi se lubanja i do lubanje ukrštene dvije kosti. ${ }^{53}$ Uz katafalk su gorjele četiri svijeće, a ispred se postavljao bijeli ili srebrni križ. Ovakav obred bio je u praksi sve do 1966. godine, dakle nakon Drugog vatikanskog koncila više se nije primjenjivao. U crkvi u Batini Donjoj, koja je u blizini Belca, a pripada Župi Zlatar, ovakav obred nije bio uobičajen, no ispod kora prema izlazu bila je postavljena lubanja na stupiću. Da se obred na ovakav način služio u belečkoj župi, potvrdio je i mons. Zvonimir Kurečić, koji navodi da se također služio i u zlatarskoj župi te da se nazivao opslužavanje. ${ }^{54} \mathrm{U}$ belečkoj se župi najčešće koristio izraz rekvijem prema prvom zazivu pristupne molitve 


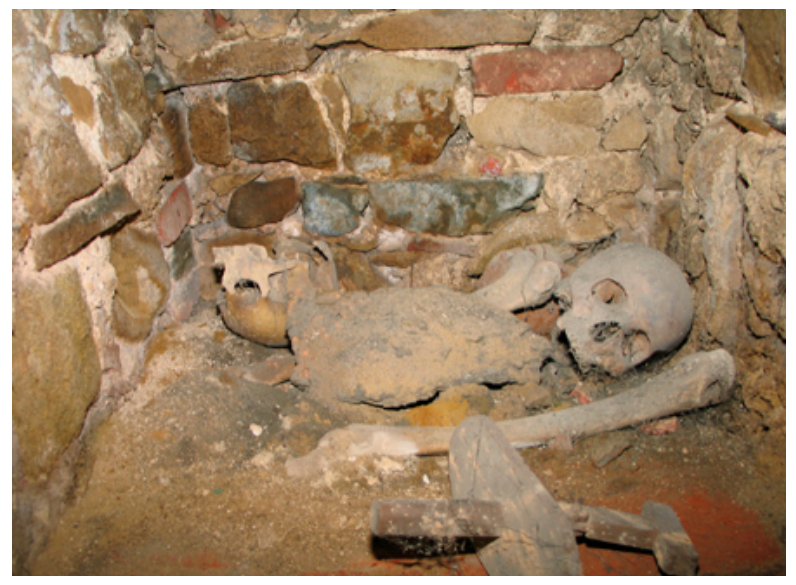

21. Taborsko, crkva Blažene Djevice Marije, lubanje sa stražnje strane menze glavnog oltara (snimka: M. Pavličić, 2010.) Taborsko, Church of the Blessed Virgin Mary, skulls on the back of the main altar stone (M. Pavličić, 2010)

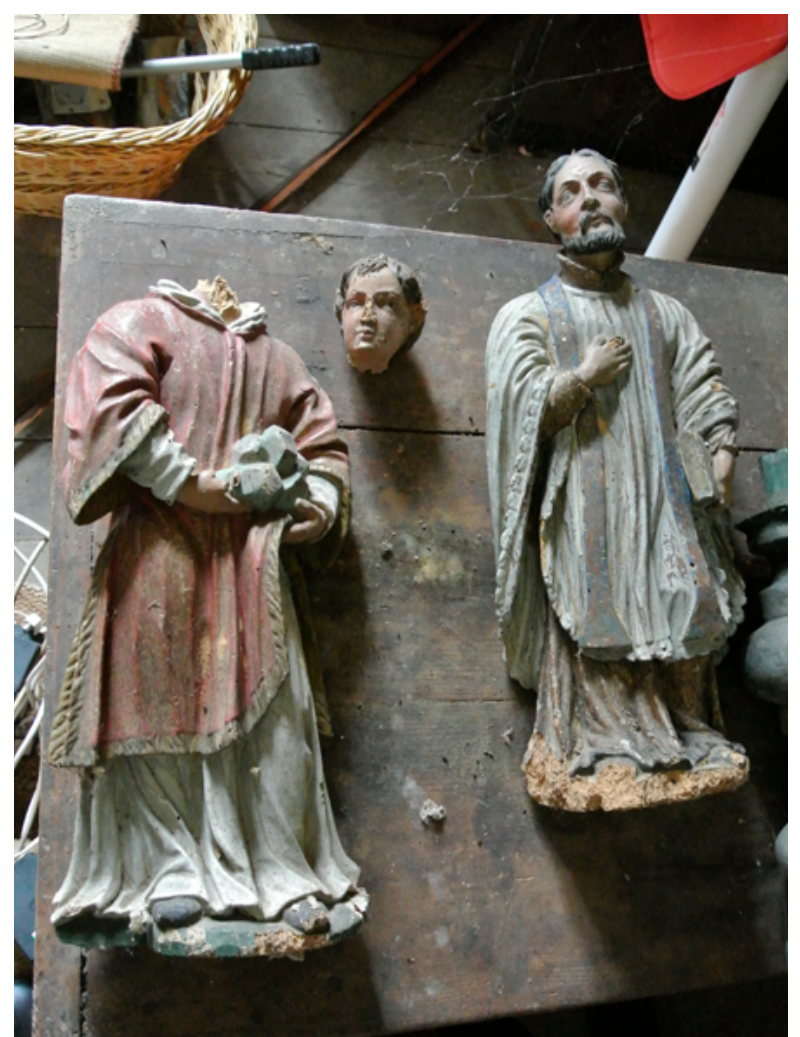

22. Kipovi sv. Stjepana i sv. Franje Ksaverskog u župnom dvoru (snimka: I. Sambolić, 2021.)

Statues of St Stephen and St Francis Xavier in the rectory (I. Sambolić, 2021)

(lat. introitus) u takvoj svetoj misi za pokojne - Requiem aeternam dona eis Domine; et lux perpetua luceat eis. ${ }^{55}$

$\mathrm{Na}$ ovakav se način služila i misa na Dušni dan, a nakon mise lubanja se pospremala u posebnu udubinu iza oltara. ${ }^{56}$ Ovakva udubina, u kojoj su bile pohranjene kosti i lubanje, otkrivena je u crkvi Blažene Djevice Marije $u$ Taborskom iza glavnog oltara tijekom radova preventivne zaštite 2010. godine koje je izvodio HRZ (sl. 21). Nadalje, vlč. Milan Pušec, upravitelj Župe Konjščina (koja se nalazi do belečke župe), našao je ljudsku lubanju i crno pokrivalo u župnoj crkvi sv. Dominika 2016. godine, kada je postao upravitelj župe. S obzirom na ove nalaze, može se pretpostaviti da je ovakav način obreda bio raširen na području Zagorja.

Dodatna potvrda obavljanja ovakvog obreda u belečkoj župi bila bi postojanje misala prema kojem su se služile ovakve mise, stoga se počelo tragati za njim. Prilikom potrage za misalom, $u$ pokrajnjoj sobi na župnom dvoru, pronađeni su i kipovi s atike za koje se mislilo da su u međuvremenu izgubljeni - ispod hrpe tkanina na komodi bile su sakrivene skulpture sv. Stjepana i sv. Franje Ksaverskog (sl. 22).

Pregledom župnog arhiva pronađen je misal Ordo missae pro defunctis (Red mise za mrtve) iz 1871. godine, $\mathrm{u}$ kojem je naveden i obred koji se služi bez tijela pokojnika u crkvi. U Priručniku za vršenje službe Božje po propisima rimskoga obreda koji je sastavio Stjepan Gjanić 1919. godine, stoje upute za služenje mrtvačke mise (Missae de Requie), gdje kod općenitih propisa stoji: „Misno je odijelo crno, a tako i antipendium, zastor tabernakula (conopaeum) ljubičast.“" ${ }^{57}$ Slične upute su navedene $u$ Kniewaldovoj Liturgici - žrtvenik na kojem se služi misa mora biti pokriven s tri oltarnika, a s prednje strane treba biti palij ili antependij, koji bi, po mogućnosti, odgovarao boji dana ili službe. Malo dalje navedeno je sljedeće: „Kod svečane mise treba da gori šest svijeća, a kod pjevane crne mise barem četiri. “58 Iz Liturgike se saznaje i u kojem je razdoblju moguće služiti ovakve mise: „Misa se za pokojne služi na dušni dan iza None. ${ }^{59}$ Isto se tako može služiti iza None i u dan pokopa, kao i treći, sedmi i trideseti dan, i u svečanu godišnjicu, kad je tom zgodom concursus populi. Inače se misa za pokojne služi iza Prime.“60

Nadalje, u Priručniku za vršenje službe Božje po propisima rimskoga obreda date su upute za služenje Apsolucije za mrtve (Absolutio pro defunctis) kada tijelo pokojnika nije prisutno u crkvi (Absente corpore) ${ }^{61}$ a koja se služi prema gore navedenom vremenskom razdoblju:

„1. U crkvi na stalnom mjestu treba da bude podignut mrtvački odar (tumulus, tumba, katafalk), oko njega svijeće, na njemu križ, može se staviti cvijeće i insignia. Svijeće treba da pod misom gore.

2. Poslije mise spremanje i procesija kao gore. Poređaj oko tumbe uvijek onako kao gore za mrtvaca, koji nije svećenik: dakle, C ostane gore izmedu oltara i tumbe a $\mathrm{S}$ s križem između tumbe i vrata. Izuzetak je, kako je već rečeno, ako je pogrebna misa za svećenika corpore insepulto vel non ulta, biduunm sepulto, jer se tada ima prolaziti kako je rečeno gore pod a) 8. U svim drugim slučajevima i za svećenika ima biti kao i za sve druge.“ ${ }^{\text {62 }}$

Rezultat ovog istraživanja dao je odgovor koja je bila svrha motiva memento mori na antependiju - imao je 


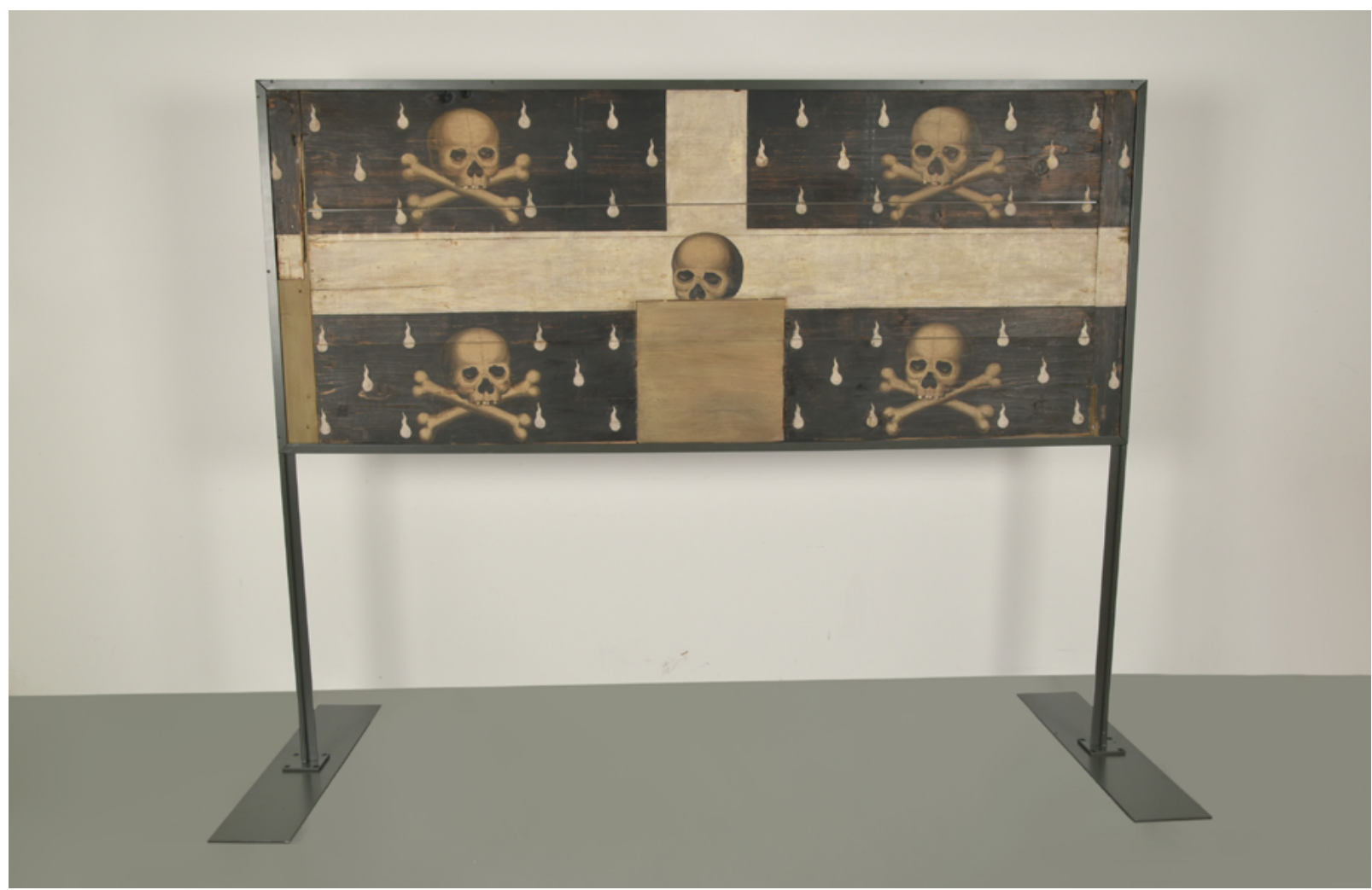

23. Bouxurulle, crkva Saint-Maur, antepedij Klanjanje Presvetom Sakramentu, 18. stoljeće (arhiva l'Atelier Régional de Conservation ARCNucléart de Grenoble, @ARC Nucléart, 2016.)

Bouxurulle, Saint-Maur church, antependium Adoration of the Blessed Sacrament, $18^{\text {th }}$ century (l'Atelier Régional de Conservation ARCNucléart de Grenoble, archive, (C) ARC Nucléart, 2016)

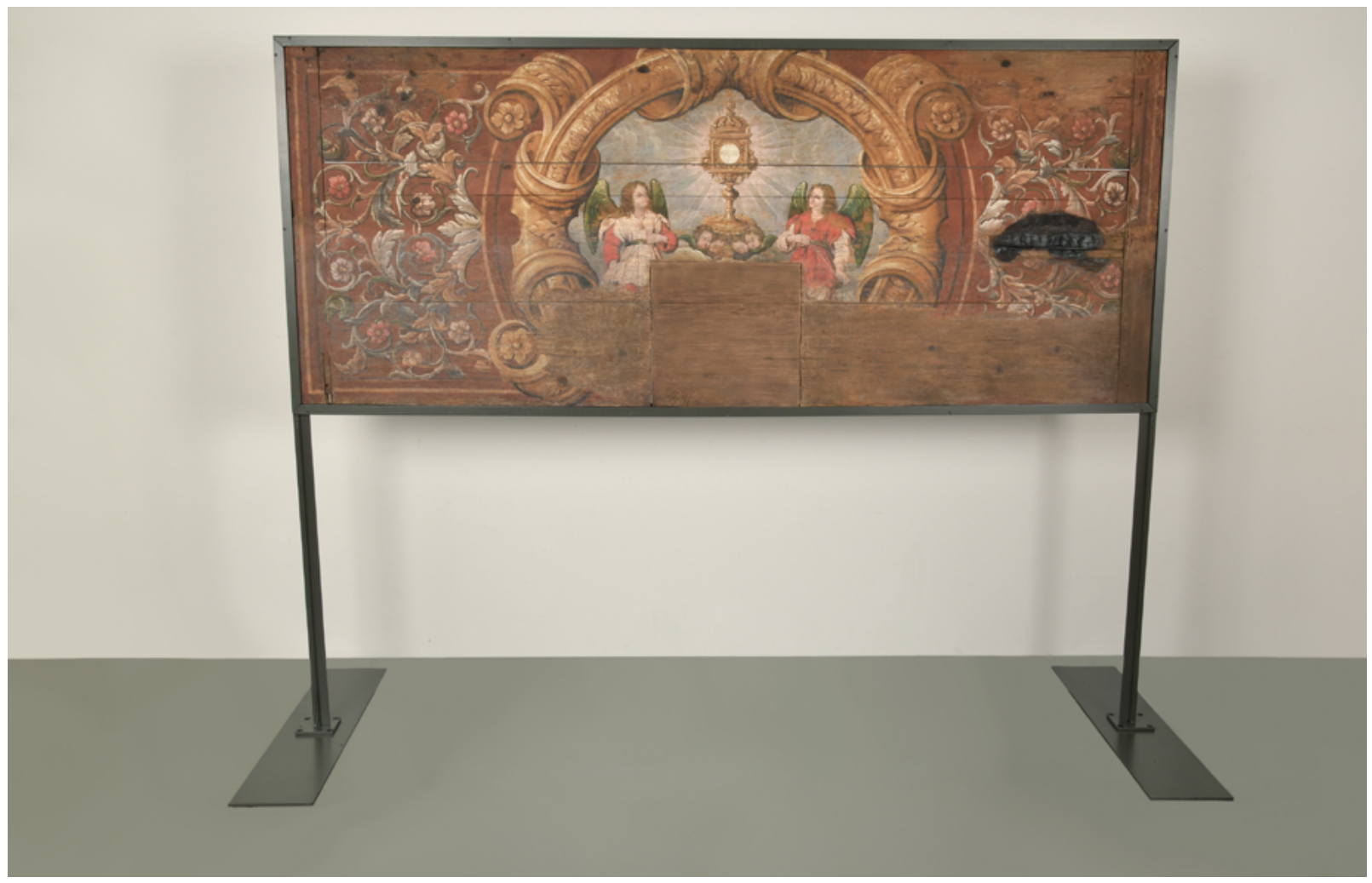

24. Bouxurulle, crkva Saint-Maur, antepedij Klanjanje Presvetom Sakramentu, 18. stoljeće, Memento mori na stražnjoj strani (arhiva l'Atelier Régional de Conservation ARC-Nucléart de Grenoble, (ARC Nucléart, 2016.)

Bouxurulle, Saint-Maur church, antependium Adoration of the Blessed Sacrament, $18^{\text {th }}$ century, Memento mori on the back ('Atelier Régional de Conservation ARC-Nucléart de Grenoble, archive, (c) ARC Nucléart, 2016) 
ulogu u vršenju liturgije. U prilog ovoj tezi ide i već spomenuta činjenica da je župnik Tompić nabavio „crninu za mrtvike i svečane requieme za 25 for“. Koliko je takva praksa bila važna ili česta, može se samo pretpostavljati, no crkva sv. Jurja ima očitu korelaciju s prvom od posljednje četiri stvari. Tu je otkriće sarkofaga (sl. 11) ispod slijepih lukova uz sjeverni zid kod kojega se u veću komoru polagao pokojnik, dok su se kosti prethodno sahranjenog odlagale u manju komoru - osarij, što crkvu čini jedinim zasada poznatim karnerom u Hrvatskoj. Osim toga, u njoj su se sahranjivali članovi plemićkih obitelji iz šire okolice i župnici. Prema vizitacijama $u$ malenoj je crkvi bilo čak devet grobnica u kojima su svoje počivalište, osim župnika, našli članovi sljedećih obitelji: Bužanić, Jelačić, Zaverški, Aras, Plenar, Vitez, Erdödy i Kiš, no tijekom radova sanacije poda, 80 -ih godina prošlog stoljeća, sve su grobnice zatečene ispražnjene.

Oko crkve nekad se nalazilo groblje na kojem su se pokapali župljani i kapela sv. Mihovila, koja je, prema opisu, bila manjih dimenzija, zidana, s drvenim stropom i krovom od drvenih daščica, koja je već 1768 . godine opustošena. Groblje uz crkvu sv. Jurja bilo je napušteno 1819. godine te je 20. lipnja 1819 . godine otvoreno novo groblje na crkvenom zemljištu u blizini crkve, no samo na razdoblje od 54 godine jer je već 1873. preseljeno na

\section{Bilješke}

1. Usp. HORVAT, 1982, 5, 241; MAROEVIĆ, SMAILAGIĆ, 1975, 117.

2. SZABO, 1914, 140.

3. Prvo spominjanje kao crkve belečke župe, po Klaiću je već 1242. u ispravi bana Dimitrija, gdje bi se hominess cruciferorum de sancto Georgio odnosilo na ovu kapelu, o čemu piše u bilješkama Diana Vukičević-Samaržija. VUKIČEVIĆ-SAMARŽIJA, 2008, 728.

4. NAZg, Fond osobne ostavštine Đure Pukeca, V. Noršić, 1917. - 1925., Povijest župe Majke Božje Snježne u Belcu, rukopis, kutija 9. Vidi također: NORŠIĆ, 1952; MAROEVIĆ, SMAILAGIĆ, 1975.

5. Arhiv Župe Belec, Račun kapele sv. Jurja pod Belcem od godine 1885., rukopis na hrvatskom jeziku.

6. Drago Miletić istražuje i iznosi političko-društveno-gospodarske okvire belečkog područja te povijesno-umjetničku obradu crkve sv. Jurja. HRZ, Drago Miletić, Belec - crkva sv. Jurja. Dosje RZH br. 95, 1984.

7. Usp. MILETIĆ, 2010, 43.

8. Promjene na crkvi sv. Jurja koje su navedene u vizitacijama, ovdje su opisne kako ih je dokumentirao Noršić, jednako kao i u: MILETIĆ, 2010.

9. Naselja i njihov razvoj naveden je kako bi se dodatno razjasnila nedoumica oko toga kako je nastalo naselje Belec te zašto se u pojedinim literarnim izvorima navodi da je crkva sv. Jurja u Juranščini, a negdje da je u Belcu, vidi: MILETIĆ, 2010.

10. SZABO, 1914, 140.

11. „Kula, branič - (prijevod njem. Bergfried) - branič-kula je uvriježeni naziv za glavnu, a često i jedinu kulu unutar srednjovjekovne osamljeni brežuljak uz cestu prema Budinščini. U svakom je slučaju sve to vrijeme briga za pokojnike bila vrlo živa i važna. Slične prakse nisu obrađene u zasada dostupnoj stručnoj literaturi, a niti je slučaj ovakvog korištenja antependija koji bi imao motiv memento mori poznat kolegama u muzeju koji je posvećen pitanjima umiranja, smrti, pokopa, žalosti i sjećanja u Kasselu - Museum für Sepulkralkultur Kassel. ${ }^{63}$ U Francuskoj postoji svega nekoliko sačuvanih primjerka dvostrano slikanih antependija koji na stražnjoj strani imaju prikaz motiva memento mori, a jedan je od njih slučajno pronađen 2014. godine u crkvi Saint-Maur u Bouxurullesu, ${ }^{64}$ prilikom radova na stolarskoj sanaciji drvenog inventara crkve. Na drvenom je nosiocu s prednje strane naslikana scena Klanjanje Presvetom Sakramentu, a sa stražnje je strane memento mori , koji se okretao prilikom pogrebnih rituala, na što ukazuju tragovi kuka koji su otkriveni prilikom konzervatorsko-restauratorskih radova $u$ restauratorskoj radionici ARC-Nucléart u Grenobleu (sl. 23 i 24). Projekt obnove ovog antependija općina Bouxurulles je prijavila na natječaj za očuvanje baštine francuskih općina Sačuvaj baštinu svoje općine, koji svake godine organizira Commissariat à l'énergie atomique et aux énergies alternatives (CEA), ${ }^{65}$ te je iste godine projekt proglašen laureatom. U Belcu bi rekli „Bogeku fala i naš je zglihal“.

utvrde; njezina je funkcija prvenstveno obrambena, iako je jedan od katova često bio uređen za stanovanje ili privremeni smještaj, posebno ako u utvrdi nema drugih stambenih prostorija; naziv je vjerojatno preuzet/preveden iz njemačkog govornog područja gdje tip kule Bergfried doslovno znači „čuvar mira“; branič-kula najčešće ima tri kata, ulaz je na prvom katu preko odvojivih ljestvi, a na vrhu je branište“ https://darkoantolkovic.wordpress. com/2017/03/01/pojmovnik-utvrdnog-graditeljstva-s-nazivljemna-engleskom-jeziku/ (20. 4. 2021.).

12. MILETIĆ, 2010. Miletić u svom radu razmatra istraživanja i zaključke Tihomila Stahuljaka, Ljube Karamana, Diane Vukičević Samardžije i Zdenka Baloga.

13. BALOG, 2009, 42; MILETIĆ, 2010, 49.

14. Usp. MILETIĆ, 2010, 63; IVANČEVIĆ, 2000, 595; https:// www.hrz.hr/index.php/aktualno/europska-godina-kulturnebastine/2938-belec-crkva-sv-jurja (24. 6. 2021.).

15. NAZg, Fond osobne ostavštine Đure Pukeca, V. Noršić, 1917.1925., Povijest župe Majke Božje Snježne u Belcu, rukopis, kutija 9.

16. REPANIĆ BRAUN, 2008, 726.

17. SZABO, 1914, 141.

18. Arhiv Župe Belec, u radu je korišten Liber Memorabillium Parochiae Belecensis ab Anno 1865 ili Zapisnik Uspomenah župe Belečke (Spomenica Župe Belec) od god 1865., doslovni prijepis koji bilježi događaje do 1938., međutim ne za svaku godinu u 20. stoljeću. Ovaj je prijepis nastao 13. ožujka 1973.

19. Arhiv Župe Belec, Spomenica Župe Belec, 41-42. 
20. Arhiv Župe Belec, Spomenica Župe Belec, 53.

21. Arhiv Župe Belec, Spomenica Župe Belec, 54.

22. Arhiv Župe Belec, Spomenica Župe Belec, 76.

23. Arhiv HRZ-a, dosje 95, god 1993. Belec crkva sv. Jurja, projekt prezentacije, zima 1993. RZH.

24. Tijekom radova 2018. godine izmjerene su dimenzije antependija s ukrasnim okvirom $97 \times 150 \mathrm{~cm}$, a dimenzije antependija $91,2 \times 144,5 \mathrm{~cm}$.

25. Arhiv HRZ-a, Kartoteka popravljenih umjetnina Hrvatskog narodnog muzeja za umjetnost i obrt, broj kartoteke 405. Podatci o izvedenim radovima također u: MILETIĆ, 2010, 51.

26. U bilješkama se spominje kako su slike bile restaurirane između 10. i 20. prosinca i zatim vraćene u crkvu na njihova mjesta 26. prosinca 1947. MILETIĆ, 2010, 66.

27. Arhiv HRZ-a, dosje 95, RZH, Izvještaj o radovima u 1972.

28. Arhiv HRZ-a, dosje 95, RZH, Izvještaj o radovima u 1973.

29. Usp. BARIČEVIĆ, 1972, 285-286.

30. NAZg, Bar. Do. 1519-1524, na poleđini fotografije upisan je datum 23.07.1968.

31. Arhiv HRZ-a, Župa Belec, odn. župljani, participirali su u troškovima radova 1972. s $40 \%$, iako je riječ o siromašnoj župi. Već 1973. vlč. Bacinger piše RZH-u dopis u kojem župsko vijeće upozorava da je taj iznos previsok za siromašne župljane, te kako bi participacija trebala biti manja s obzirom na to da je riječ o spomeniku kulture važnom ne samo za župu.

32. Cijelu problematiku koja je utjecala na nestručna rješenja, donosi Sandra Križić Roban. KRIŽIĆ ROBAN, 1999.

33. Radovi na oltaru izvode se u privatnoj radionici Modulor modeli d.o.o, a voditelj radova je Ivan Duraković.

34. Antependij sam otkrila s vlč. Draženom Radigovićem prilikom izrade imovnika župe i potrage za starim sakristijskim ormarom iz župne crkve koji se navodio u popisu inventara u župnom arhivu, a kojem se gubio trag i u Konzervatorskom odjelu Krapina. Imovnik je trebalo pripremiti radi preuzimanja Župe nakon smrti belečkog župnika vlč. Mirka Borjana. U istoj prostoriji gdje je pronađen antependij, bili su i gornji dijelovi sakristijskog ormara.

35. Usp. DRAGIĆ, 2013, 273.

36. Repanić Braun datira sliku oko 1740. REPANIĆ BRAUN, 2008, 726.

37. Arhiv HRZ-a, dosje 4974, prema podacima u dosjeu, pretpostavlja se da je autor Ranger, a slika je datirana oko 1750 . godine. Na slici su u 2000. izvedeni cjeloviti konzervatorskorestauratorski radovi.

38. BARIČEVIĆ, 1972, 285.

39. WOLFF ZUBOVIĆ, 2017, 52. Antependij sa sličnom ornamentikom nalazi se u Muzeju za umjetnost i obrt u Zagrebu: https:// repozitorij.muo.hr/?pr=i\&id=37633 (14. 9. 2021.).

40. LENKOVIĆ, 2020, 339.

41. BADURINA, 1979, 568; CHEVALIER, GHEERBRANT, 2007, 308, 547.

42. „Lubanja se često prikazuje između dviju na X prekriženih goljeničnih kostiju, oblikujući tako križ sv. Andrije, simbol raščetvorenja naravi pod nadmoćnim utjecajem duha, pa prema tomu i simbol duhovnog savršenstva." CHEVALIER, GHEERBRANT, 2007, 386.

43. U središnjem dijelu uz gornji rub, na strani sa sv. Jurjem, bio je vidljiv zakit s preslikom tamnijeg oker tona, a još su mjestimično bili naneseni preslici na plavoj pozadini, koji su s vremenom potamnjeli te ne nisu odgovarali tonu izvornog slikanog sloja. 44. Analize su pokazale tamnocrveno toniranu preparaciju, $u$ čijem je sastavu putem XRF i SEM-EDS analize pronađen željezni oksid, silikati, titanov oksid i gips. Titanov oksid prisutan je samo u sloju preparacije, što može upućivati da je riječ o primjesi koja se našla uz pigmente koji u svom sastavu imaju željezne okside. Sličnu pojavu titanovog oksida u sloju preparacije, može se naći u mikropresjecima slike Polaganje u grob iz župne crkve Sv. Petra i Pavla, Sveti Petar u Šumi, 18 stoljeće Detaljnije u: HRZ, Laboratorijsko izvješće br. 295/2018; HRZ, Laboratorijsko izvješće br. 167/2018.

45. Uklanjanje površinskog premaza izvedeno je pomoću emulzije ulja u vodi, pH 6 (kao tenzid korišten je Pemulen TR2, a za uljnu je komponentu korišten benzilni alkohol), dok su preslici uklonjeni pomoću lužnatog gela, pH 8. Nosilac se ravnao optežavanjem između bugačica prethodno navlaženih mješavinom etilnog alkohola i destilirane vode, s obzirom na to da, zbog obostrano slikane površine, ravnanje na toplinskom vakuum stolu nije bila prihvatljiva metoda. Kod rekonstrukcije manjkajućih dijelova osnove korišten je kit u kojem je vezivo polivinil acetat, a kao punilo korišteni su kalcijev karbonat, kalcijev sulfat dihidrat i željezni oksid. Podlaganje crvenog tona retuša izvedeno je gvašem tvrtke Winsor \& Newton kako bi se površina što više uskladila s okolnim stanjenim slikanim slojem ispod kojeg se nazirala crvena preparacija. Završna je faza retuša izvedena pomoću Maimeri boja, nakon čega je izvedeno lakiranje mastiks lakom. Potom je antependij napet tako da se dužinom rubova traka lanenog platna, zalijepljenih filmom ljepila Beva 371, umetnula čelična šipka na koju je na svakih $10 \mathrm{~cm}$ postavljena opruga s vijčanom zategom od nehrđajučeg čelika, a ista se nakon napinjanja učvrstila pomoću vijka u letvicu ukrasnog okvira. Ova metoda napinjanja primijenjena je na antependiju zahvaljujući kolegi Pavlu Lerotiću.

46. Usp. DRAGIĆ, 2013, 272.

47. Katekizam Katoličke crkve: kompendij, 2008, 60.

48. LEON-DUFOR, 1980, 1211.

49. REBIĆ, 2003,72; DUTTON, 2019, 3.

50. GERM, 2014, 313-326, vidi također: PELC, 2004, 127-145.

51. KANIŠKI, 2011, 313-318.

52. Osobni intervjui na području Župe Belec: 5. 4. 2021. Štefa Škof (Batina Gornja, rođ. 8. 2. 1941.), 5. 8. 2019.: Ljubica Havoić (Belec, rođ. 29. 12. 1939.), 26. 12. 2018.: Ivka Sambolić (Selnica Gornja, rođ. 28. 4. 1938.); osobni intervju na području Župe Zajezda: 21. 8. 21. Đurđa Zajec (rođ. 16. 1. 1935.). U Župi Zajezda rekvijem se rijetko služio i tada je postavljen katafalk/lijes prekriven crnim platnom bez lubanje.

53. Mogući razlog postavljanja lubanje bio bi isprepleten odnos duše i tijela u srednjem vijeku, u kojem je tijelo (kostur) bio simbol za dušu. Lubanje su bile izložene čak i prilikom služenja mise, 
gdje su u kosturnicama bile okrenute prema oltaru. ĐORĐEVIĆ, 2014, 51; ĐORĐEVIĆ, 2017, 3, 6.

54. Veliku zahvalnost dugujem mons. Zvonimiru Kurečiću, rodom iz Zlatara, čiji su savjeti glede literature vezane uz liturgiju i tumačenja načina na koji su promjene u liturgiji nastupile nakon Drugog vatikanskog koncila, bili dragocjeni, a mnogobrojni razgovori poticajni, ugodni i konstruktivni. Mons. Kurečić je kao ministrant dolazio u Belec za vrijeme službovanja vlč. Rogine te je bio i više nego dobro upoznat kako s načinom crkvene službe u belečkoj i zlatarskoj župi tako i s obredom „črne meše“ ili „opslužavanja“. Također zahvaljujem fra Bernardu Barbariću na dostavljenoj literaturi i smjernicama.

55. Arhiv Župe Belec, Ordo Missae pro defunctis, 1871, 25.

56. U osobnom intervjuu župljanka Štefa Škof navodi kako su prije ovakve mise-rekvijema zvonila crkvena zvona na poseban način, pa su župljani po zvuku zvona razlikovali kakva misa se služi. 57. GJANIĆ, 1919, 20.

58. KNIEWALD, 1937, 116.

59. Praksa moljenja kroz dan kod ranih kršćana preuzeta je iz judaizma, a za vrijeme rimskog carstva ustaljeni su nazivi na latinskome jeziku; prima (prva jutarnja svijetlost) je razdoblje od 6:00 do 9:00 sati, terca je od 9:00 do 12:00, seksta - šesti čas je 12:00 do 15:00, nona je deveti čas i odnosi se na razdoblje od 15:00 do 18:00 sati; vespera je razdoblje od 18:00 do 21:00. Šest sati u noći zovu se Vigiliae i ovaj naziv se odnosio na noćne satove straže vojnika. Noć od šest sati navečer do šest sati ujutro bila

\section{Izvori}

HRZ Hrvatski restauratorski zavod

MKM-FKB Ministarstvo kulture i medija Republike Hrvatske, Zbirka fotografske dokumentacije NAZg Nadbiskupijski arhiv u Zagrebu

\section{Literatura}

ANĐELKO BADURINA (ur.), Leksikon ikonografije, liturgike i simbolike zapadnog kršćanstva, Zagreb, 1979.

ZDENKO BALOG, Stara župna crkva svetog Jurja u Belcu i tip Chorturma, u: Sic ars deprenditur arte - zbornik u čast Vladimira Markovića, 2009., 27-43

DORIS BARIČEVIĆ, Pregled spomenika skulpture i drvorezbarstva 17. i 18. stoljeća u istočnom dijelu Hrvatskog zagorja, Ljetopis JAZU, 76 (1972.), 283-313

Biblija, Sveto pismo Staroga i Novoga zavjeta, preveo Ivan Ev. Šarić, Split, 2008.

JEAN CHEVALIER, ALAIN GHEERBRANT, Rječnik simbola: mitovi, snovi, običaji, geste, oblici, likovi, boje, brojevi, Zagreb, 2007.

MARKO DRAGIĆ, Sveti Juraj u tradicijskoj baštini Hrvata, Croatica et Slavica ladertina, 9 (2013.), 269-314

AMANDA M. DUTTON, Death becomes us: an examination of Memento mori rhetoric in the art and literature of the counter-reformation, A Dissertation Submitted to the Faculty of the Dorothy F. Schmidt College of Arts and Letters In Partial Fulfillment of the je podijeljena na četiri straže ili bdijenja po tri sata: prvo, drugo, treće i četvrto bdijenje.

60. KNIEWALD, 1937, 263.

61. GJANIĆ, 1919, 84.

62. Kratice $\mathrm{C}$ i $\mathrm{S}$ znače celebrant i subđakon.

63. lako u muzeju nisu ovakvi slučajevi poznati, tijekom istraživanja ove teme naišla sam na zanimljiv slučaj u njemačkoj pokrajni Bavarskoj, gdje se nalazi uz granicu sa Češkom u mjestu Wondreb grobna kapela Sv. Mihaela s ciklusom posvećenim smrti prikazanim na tabulatu iz 18. stoljeća, a naziva se Totentanzkapelle. U kapeli je oltar s antependijem na kojem su naslikane četiri lubanje s ukrštenim kostima i ljudskim likom u centralnom dijelu koji gori u paklenom ognju. http://www.grzesina.de/reise/tagestouren/ alwarat.html (31. 3. 2021.); https://www.katholische-sonntagszeitung.de/Im-Blickpunkt/Totentanz-Darstellungen-in-WondrebFreitag-30.-Oktober-2020-07-56-00 (31. 3. 2021.).

64. https://epinalinfos.fr/2016/11/lantependium-de-leglisesaint-maur-de-bouxurulles-musee-departemental/ (13. 5. 2019.); URL=https://actu88.fr/bouxurulles-un-chef-doeuvre-de-bas-dauteldu-xviie-restauree/ (14. 5. 2020.); https://docplayer.fr/8492134815-16.html (13. 5. 2020.); https://www.cirkwi.com/en/pointinteret/1184393-antependium-eglise-saint-maur (18. 3. 2021.).

65. Commissariat à l'énergie atomique et aux énergies alternatives (CEA) je francuska javna istraživačka organizacija koju financira vlada u području energije, obrane i sigurnosti, informacijskih tehnologija i zdravstvenih tehnologija.

Bar.Do. Osobni fond Doris Baričević

Fond osobne ostavštine Đure Pukeca, V. Noršić, 1917.- 1925., Povijest župe Majke Božje Snježne u Belcu, rukopis, kutija 9 Arhiv Župe Blažene Djevice Marije Snježne Belec

Requirements for the Degree of Doctor of Philosophy Florida, Florida Atlantic University, 2019.

JAKOV ĐORĐEVIĆ, Lepota lubanje: posmrtni ostaci "obični" mrtvi u kulturi i vizualnoj kulturi kasnog srednjeg veka, u: Jezici i kulture u vremenu i prostoru, IV/1,2014., 43-54

JAKOV ĐORĐEVIĆ, Made in the skull's likeness: of transi tombs, identity and memento mori, u: Journal of Art Historiography, 17 (2017.), 3-19

MARTIN GERM, Saltus Mortis in Valvasor's Theatrum Mortis Humanae Tripartitum A Copy of Holbein's Dance of Death?, IKON, 7 (2014.), 313-326

STJEPAN GJANIĆ, Priručnik za vršenje službe Božje po propisima rimskoga obreda, Zagreb, 1919.

ANĐELA HORVAT, Barok u kontinentalnoj Hrvatskoj, u: Anđela Horvat, Radmila Matejčić, Kruno Prijatelj, Barok u Hrvatskoj, Zagreb, 1982., 3-381

RADOVAN IVANČEVIĆ, Arhitektura od romanike do manirizma, u: Hrvatska i Europa. Kultura, znanost i umjetnost. Svezak 2: Srednji 
vijek i renesansa, ur. Ivan Supičić i Eduard Hercigonja, Zagreb, 2000., 585-612

Katekizam Katoličke crkve: kompendij, 4. izdanje, Split, 2008.

ANA KANIŠKI, Two Examples of Allegorical Figure of Death as a

Skeleton in the Northwest Croatian Art, IKON, 4 (2011.), 313-318 DRAGUTIN KNIEWALD, Liturgika, Zagreb, 1937.

SANDRA KRIŽIĆ ROBAN, Ima li nade za sv. Jurja, Vjesnik, 31. 8. 1999.

MIRELA LENKOVIĆ, Historiografija srednjovjekovnog plesa mrtvaca u europskom kontekstu, Obnovljeni Život: časopis za filozofju i religijske znanosti, 75-3, (2020.), 337-348

XAVIER LEON-DUFOR (ur.), Rječnik biblijske teologije, Zagreb, 1980. IVO MAROEVIĆ, LJERKA SMAILAGIĆ, Konzervatorski radovi u crkvi sv. Marije Snježne u Belcu, Godišnjak zaštite spomenika kulture Hrvatske, 1 (1975.), 117-144

DRAGO MILETIĆ, O građevinskim mjenama crkve sv. Jurja u Belcu - drugačije, Peristil: zbornik radova za povijest umjetnosti, 53 (2010.), 43-68

VJEKOSLAV NORŠIĆ, Opis nove župne crkve BI. Dj. Marije u Belcu god. 1758., Starine, 44 (1952.), 7-24

MILAN PELC, Memento mori: popularna teologija u slikovnoj publicistici baroka: primjeri iz Valvasorove zbirke Nadbiskupije

\section{Summary}

Ivana Sambolić

\section{A FORGOTTEN MEMENTO MORI FROM BELEC}

The paper presents the course of events that have had a direct or indirect impact on the antependium from the main altar in the church of St George in Belec, the most significant example of a medieval country church in Croatia. The antependium of St George is painted on both sides and has a memento mori motif on the back. Conservation of the antependium was carried out in 2016, after it was discovered in the rectory. Conservation of the altar began in 2018 in a private workshop. The goal was to return the antependium to the altar and enable the presentation of both sides of the antependium after the work was complete. A decorative frame was constructed that also functioned as a subframe, because it has a system with springs with which the antependium is tensioned. In addition, the paper provides a description of the work that was carried out, and it questions the reasons for painting the memento mori motif on the back of the antependium. On the basis of research results, the possible role of this type of motif during liturgical rites relating to funerals, and other liturgical rites relat- zagrebačke, u: Religijske teme u likovnim umjetnostima: zbornik radova međunarodnog simpozija održanog u Zagrebu 13. prosinca 2003., ur. Ivan Antunović, Zagreb, 2004., 127-145

ADALBERT REBIĆ, Biblijska eshatologija, Bogoslovska smotra, 73-1 (2003.), 71-100 MIRJANA REPANIĆ BRAUN, Kapela sv. Jurja. Oprema kapele. Slike, u: Krapinsko-zagorska županija. Sakralna arhitektura s inventarom. Feudalna arhitektura. Spomen obilježja, Umjetnička topografija Hrvatske, knjiga 4, ur. Ivanka Reberski, Zagreb, 2008., 726 GJURO SZABO, Spomenici kotara Krapina i Zlatar, Vjesnik Hrvatskog arheološkoga društva, 13/1 (1914.), 103-204

DIANA VUKIČEVIĆ SAMARŽIJA, Gotičke crkve Hrvatskog zagorja, Zagreb, 1993.

DIANA VUKIČEVIĆ-SAMARŽIJA, Kapela sv. Jurja, u: Krapinskozagorska županija. Sakralna arhitektura s inventarom. Feudalna arhitektura. Spomen obilježja, Umjetnička topografija Hrvatske, knjiga 4, ur. Ivanka Reberski, Zagreb, 2008., 722-727

MARTINA WOLFF ZUBOVIĆ, Tipologija i podrijetlo ornamentike na drvenim oltarima XVII. i XVIII. stoljeća na području sjeverozapadne Hrvatske - recepcija, primjena i razvoj motiva, svezak I. doktorski rad, Zagreb, Sveučilište u Zagrebu, Filozofski fakultet, 2017.

ing to the deceased (no longer performed in Belec after the Second Vatican Council), was presented. Personal interviews and research conducted by studying archival data showed that the church of St George served Mass for the deceased with a catafalque, or an empty coffin covered with a black cloth, with skull and crossbones on top. For this type of Mass, called 'black mass' (črna meša) or requiem, the altar linens had to be black, so it can be concluded that the back of the antependium with the memento mori motif was displayed for such occasions. The practice has almost completely fallen into oblivion, and there are only a few preserved antependia in Europe with a memento mori painted on the back. Given that human skulls and bones were found behind the main altar in Taborsko in 2010, serving this type of Mass was probably widespread in the Hrvatsko Zagorje region.

KEYWORDS: church of St George, Belec, antependium painted on both sides, Memento mori, requiem, 'black mass', skull, Taborsko, Hrvatsko Zagorje region 
